\title{
Investment in carbon dioxide capture and storage combined with enhanced water recovery
}

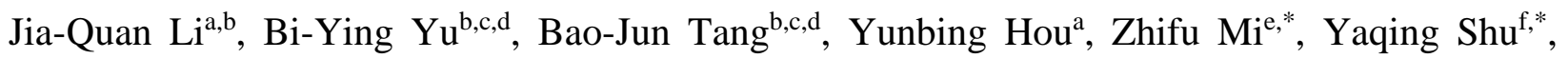
Yi-Ming Wei ${ }^{\mathrm{b}, \mathrm{c}, \mathrm{d}, *}$

${ }^{\text {a }}$ College of Resources and Safety Engineering, China University of Mining and Technology (Beijing), Beijing 100083, China

${ }^{\mathrm{b}}$ Center for Energy and Environmental Policy Research, Beijing Institute of Technology, Beijing 100081, China

${ }^{c}$ School of Management and Economics, Beijing Institute of Technology, Beijing 100081, China

d Beijing Key Lab of Energy Economics and Environmental Management, Beijing 100081, China

${ }^{\mathrm{e}}$ The Bartlett School of Construction and Project Management, University College London, London WC1E 7HB, UK

${ }_{\mathrm{f}}^{\mathrm{f}}$ Department of Transport \& Planning, Faculty of Civil Engineering and Geosciences, Delft University of Technology, Stevinweg 1, PO Box 5048, 2600 GA Delft, The Netherlands

* Corresponding authors Y.-M.Wei (wei@bit.edu.cn), Z.Mi (z.mi@ucl.ac.uk), Y. Shu (y.shu@tudelft.nl) 


\title{
Investment in carbon dioxide capture and storage combined with enhanced water recovery
}

\begin{abstract}
Carbon dioxide capture and storage combined with enhanced deep saline water recovery (CCS-EWR) is a potential approach to mitigate climate change. However, its investment have been a dilemma due to high costs and various uncertainties. In this study, a trinomial tree modelling-based real option approach is constructed to assess the investment in CCS-EWR retrofitting for direct coal liquefaction in China from the investor perspective. In this approach, the uncertainties in $\mathrm{CO}_{2}$ prices, capital subsidies, water resource fees, the residual lifetime of direct coal liquefaction plants, electricity price, $\mathrm{CO}_{2}$ and freshwater transport distance, and the amount of CERs (certified emission reductions) are considered. The results show that the critical CERs price for CCS-EWR retrofits is $7.15 \mathrm{CNY} /$ ton (Chinese Yuan per ton) higher than that (141.95 CNY/ton) for CCS retrofits. However, the exemption from water resource fees for freshwater recovered from saline water and a subsidy of $26 \%$ of the capital cost are sufficient in eliminating the negative impact of enhanced deep saline water recovery (EWR) on the investment economy of CCS-EWR. In addition, when the residual lifetime is less than 14 years, CCS-EWR projects are still unable to achieve profitability even with flexible management and decision making; therefore, investors should abandon CCS-EWR investments. On the whole, the investment feasibility for CCS-EWR technology is not optimistic despite having access to preferential policies from the government. It is necessary to establish a carbon market with a high and stable CERs price.
\end{abstract}

Highlights:

- Real option approach is used to assess CCS-EWR investment decisions.

- The critical CERs price for CCS-EWR is 7.15 CNY/ton higher than that for CCS.

- EWR with exemption from water resource fees has potential investment economy.

- The investment feasibility is not optimistic.

Key words: Direct coal liquefaction; CCS; Uncertainties; Real option approach; Investment 


\section{Introduction}

Climate change is a major challenge facing the human race regarding human survival and development in the 21st century (Hoeghguldberg and Bruno, 2010; NDRC, 2016; Rosenzweig and Parry, 1994). Addressing climate change has become a worldwide consensus (IPCC, 2014). Carbon dioxide capture and storage (CCS) technology plays an important role in addressing climate change, especially in achieving the global warming target of $2^{\circ} \mathrm{C}$ (IEA, 2016; IPCC, 2015; İşlegen and Reichelstein, 2011; Scott et al., 2013). Geological sinks for $\mathrm{CO}_{2}$ include oil and gas fields, unmineable coal seams, and deep saline aquifers. Compared with oil and gas fields and unmineable coal seams, deep saline aquifers are considered to be the best potential reservoirs for $\mathrm{CO}_{2}$ storage because of their large storage capacities and widespread distribution ( $\mathrm{Li}$ et al., 2015). The large-scale geological storage of $\mathrm{CO}_{2}$, however, may cause formation pressure changes, which in turn leads to the migration of saline water and the leakage of $\mathrm{CO}_{2}$ (Birkholzer et al., 2009). A novel option, CCS combined with enhanced deep saline water recovery (CCS-EWR), has been proposed in recent years. The setting of pumping wells can control the reservoir pressure effectively (Buscheck et al., 2016; Buscheck et al., 2012; Wolery et al., 2009). Moreover, the extracted saline water can be recycled after desalination to alleviate water shortages (Kobos et al., 2011; Li et al., 2014). Although the CCS-EWR technology has the benefits of reducing emissions and saving water for emission sources with CCS-EWR, its profitability is the core concern of investors. Moreover, CCS-EWR is a combination of relatively independent technologies, CCS and enhanced deep saline water recovery (EWR). CCS refers to the technology for $\mathrm{CO}_{2}$ capture, transportation and storage. EWR refers to the technology for saline water treatment, freshwater utilization, and residual brine treatment. So here is the question, is EWR going to have a positive impact on the economic performance of CCS-EWR?

As one of the strategic technologies to ensure China's energy security, coal-to-liquids technology has attracted the attention of the Chinese government and has experienced rapid development in northwest China. So far as anyone can tell, water shortages are serious in the region. Coal-to-liquids plants are generally large $\mathrm{CO}_{2}$ emission sources and have the characteristics of high water consumption. China, the world's largest emitter of $\mathrm{CO}_{2}$ (Mi et al., 2017a; Mi et al., 2017b), is facing huge pressure to reduce emissions. The coal-to-liquids technology is facing the great obstacles of high $\mathrm{CO}_{2}$ emissions and water consumption (NEA, 2017). Therefore, the CCS-EWR technology with the benefits of emission reduction and water saving for emission sources and CCS-EWR can be attractive to coal-to-liquids plants. The Shenhua Group, a large multinational energy company engaged in coal production, power generation, coal chemicals production, etc. (Shenhua Group, 2018), has conducted a demonstration project of $\mathrm{CO}_{2}$ capture and saline aquifer storage (100 ktons/year (kilotons per year)) relying on a direct coal liquefaction plant in Ordos, Inner Mongolia.

Therefore, this paper try to explore the investment economy of CCS-EWR and the impact of EWR 
on the economic performance of CCS-EWR based on a case of CCS-EWR retrofitting for a direct coal liquefaction plant in Ordos.

\section{Literature review}

Reviewing the existing research, it can be concluded that the economic performance of CCS and saline water treatment has received extensive attention, but the investment feasibility of the combined system, CCS-EWR, has not been fully evaluated. The cost of CCS retrofitting for coal-to-liquids is approximately USD 20/ton (Mantripragada and Rubin, 2011). Based on the fact that the transportation and storage costs are basically the same as those chosen by Mantripragada and Rubin (2011), Xiang et al. (2014) pointed out that the cost of CCS retrofitting for coal-to-olefins is approximately $150 \mathrm{CNY} / \mathrm{ton}$ (Chinese Yuan per ton). In addition, Zhou et al. (2011) conducted economic evaluation and technical analysis of CCS retrofitting for indirect coal liquefaction based on process simulation, focusing on the comparison of $\mathrm{CO}_{2}$ capture cost respectively with three capture modes: dimethyl carbonate, monoethanolamine and rectisol. Zhou et al. (2014) examined the decision-making process of CCS retrofitting for indirect coal liquefaction projects under uncertain climate policy in China. For saline water treatment, the great pressure that exists in the process of $\mathrm{CO}_{2}$ storage ensures no additional pressurization in reverse osmosis desalination. In addition, pre-treatment is simple because of the absence of microorganisms and other impurities. At the scale of 22.7 thousand cubic metres per day, reverse osmosis plants for brines of 10-85 g/L TDS (total dissolved solids) can be built and operated for approximately half the seawater desalination costs (Wolery et al., 2009). Sullivan et al. (2013) indicated that the cost of saline water treatment is concentrated within the range of USD 0.5 2.5/ton $\mathrm{CO}_{2}$. Moreover, referring to the value created by freshwater in different industries, Zhai et al. (2016) highlighted that CCS-EWR technology has a certain economic feasibility with efficient utilization and can be widely applied in China's inland water shortage regions.

Appropriate investment evaluation methods can make the evaluation results more reasonable. The uncertainty of CCS-EWR investments is strong and complex. The existence of uncertainties is bound to result in uncertain investment income and influence investment decisions. In addition, early-stage investment in CCS-EWR is huge and irreversible (Zhou et al., 2014). Without the consideration of uncertainties in CCS-EWR investments, evaluation results may lead to a failure in decision making as well as substantial losses. CCS-EWR investments are non-mandatory, and the timing of investment is optional. Investors could postpone CCS-EWR investments and wait for favourable circumstance. At present, there are two commonly used investment evaluation methods: 1) traditional evaluation methods mainly refer to the discounted cash flow (DCF) methods represented by the net present value (NPV) method (Zhang et al., 2014) and 2) the real option approach evolves from financial option theory (Grillo 
et al., 2015). The NPV method has an obvious deficiency in the evaluation of CCS-EWR investments (Myers, 1984; Siddiqui et al., 2005), it ignores the flexibility of decision making according to future circumstances (Venetsanos et al., 2002). The real option approach has good applicability in evaluating a CCS-EWR investment due to the consideration of the uncertainties and investment flexibilities (Huchzermeier and Loch, 2001; Kulatilaka and Perotti, 1998). The investment evaluation based on the real option approach focuses on making the real option value (ROV) of CCS-EWR in an uncertain investment environment by delaying investment to avoid an unfavorable investment environment. That is, the total investment value (TIV) of CCS-EWR project is the sum of the NPV and ROV. Recently, the real option approach has been widely applied in the research of economic evaluations of CCS retrofitting for power plants and indirect coal liquefaction plants under multiple types of uncertainty (Abadie and Chamorro, 2008; Zhang et al., 2014; Zhou et al., 2010).

The timing of CCS-EWR investments is optional, which is similar to the American option in the financial options framework. The $\mathrm{N}$-ary tree method (binomial tree model and trinomial tree model) and the Monte Carlo method are the main methods of American option pricing, which are widely used in evaluating a CCS investment (Abadie and Chamorro, 2008; Zhang et al., 2014; Zhou et al., 2010). A Monte Carlo simulation is an intuitive and flexible method to simulate option prices. Moreover, it is the only method for high-dimensional random variables. For low-dimensional random variables, its advantages may be lost (Balajewicz and Toivanen, 2017). For less than three-dimensional random variables, the N-ary tree model is more appropriate because of its high efficiency (Hull, 2015). The trinomial tree model evolves from binomial model; it has three bifurcations that could be specified by defining a distribution over three states (up movement, unchanged movement, and down movement) (Ahn and Song, 2007; Yuen and Yang, 2010). The trinomial tree performs better in flexibility and precision (Tang et al., 2017; Yuen and Yang, 2010).

Firms may obtain benefits by selling CERs (certified emission reductions), which are different from the carbon quotas traded in China's current carbon market. However, CERs can be used to offset carbon quotas (NDRC, 2014). Although China does not bring CERs of CCS-EWR into the carbon market, the relevant issues are being considered with the construction of a national carbon market (CCSIC, 2016). Thus, this study assumes that CERs of CCS-EWR can be used to offset carbon quotas as well as the CERs price is equivalent to the carbon quota price in China's carbon market. Much research on CCS investment takes into account the income from the CERs (Abadie and Chamorro, 2008; Rohlfs and Madlener, 2011; Zhang et al., 2014; Zhou et al., 2010; Zhou et al., 2014). After several rounds of global climate change negotiations, global climate policy remains uncertain (Wei et al., 2014). The uncertainty of global climate policy will be reflected in the CERs price (Zhou et al., 2014). In addition, investment enterprises also face uncertainties, such as the capital subsidy (Zhang et al., 2014), residual lifetime of emission sources 
(Zhang et al., 2014), the electricity price (Chu et al., 2016; Song and Cui, 2016), the amount of CERs, $\mathrm{CO}_{2}$ and saline water (or freshwater) transport distance, and water resource fees. The amount of annual CERs is equal to the difference between the baseline emissions and project emissions and leakages (IEAGHG, 2007; UNFCCC, 2013). This paper primarily wants to evaluate the impact of the amount of CERs. The impact of capital subsidy, $\mathrm{CO}_{2}$ and saline water (or freshwater) transport distance, and residual lifetime emission sources on the investment decision is one-off. If the above four variables (include the amount of CERs, $\mathrm{CO}_{2}$ and saline water (or freshwater) transport distance, capital subsidy and residual lifetime emission sources) are set up as random variables, the results reflect the impact of their distribution function on decision-making, and the guidance provided may not be specific. For such uncertainties, it is appropriate to use scenario analysis approach to analyse their impact on CCS-EWR investment decisions. To promote the recycling of water resources, Inner Mongolia stipulates that the units of reclaimed water and mine water drawn and used shall be exempt from water resource fees (EHBWRMO, 2012). The properties of extracted saline water are similar to those of mine water. It can improve the investment economy of CCS-EWR when the recycled freshwater after desalination can get the same preferential policy as mine water. With the aggravation of the shortage of water resources, China's water resource fees will continue to increase. Therefore, the variable of water resource fees is considered to be a deterministic variable. In China, the electricity pricing is regulated by the Chinese government, which makes it rather stable compared to price evolution in Western markets (Zhou et al., 2010). Based on the trend of historical electricity price and the consideration of low-carbon technology investment in power system, China's electricity prices are expected to continue to grow in the future (Zhou et al., 2010). The CERs price is crucial to the investment of CCS-EWR. Based on the previous research (Abadie and Chamorro, 2008; Rohlfs and Madlener, 2011; Zhang et al., 2014; Zhou et al., 2010; Zhou et al., 2014), this study assumes that the CERs price is a random variable. Considering that the random variable is only the CERs price, the trinomial model is more suitable for this study.

\section{Research framework and boundary}

\subsection{Research framework}

Due to the flexible investment timing and irreversible investment of CCS-EWR, as well as the existence of a variety of uncertainties, especially the random variable CERs price, we need to use trinomial tree model-based real option theory to evaluate CCS-EWR investment feasibility. Six key indicators that provide a reference for investment decision making need to be demonstrated, including NPV, TIV, critical CERs price, critical annual increments of water resource fees, investment response time and annual investment probability. The NPV is the intrinsic value of the CCS or CCS-EWR project investment. The TIV is the sum of the NPV and ROV. The critical CERs price refers to the CERs price 
with a ROV of 0 when investors assess the economic feasibility of CCS or CCS-EWR investment for the first time. The critical annual increments of water resource fees can eliminate the negative impact of EWR on the economic performance of CCS-EWR investment on the premise of exempting water resource fees. The investment response time is the time when the investment environment meets the immediate investment requirements of CCS-EWR for the first time. The annual investment probability refers to the annual opportunity to implement the CCS or CCS-EWR investment immediately. What needs to be said here is that investors should invest immediately when the NPV is positive and the ROV is 0 . Based on the investment feasibility and the understanding of the key controllable factors influencing the decision-making, this paper puts forward the reasonable suggestion for promoting the investment of CCS-EWR. Fig. 1 shows the research framework we describe.

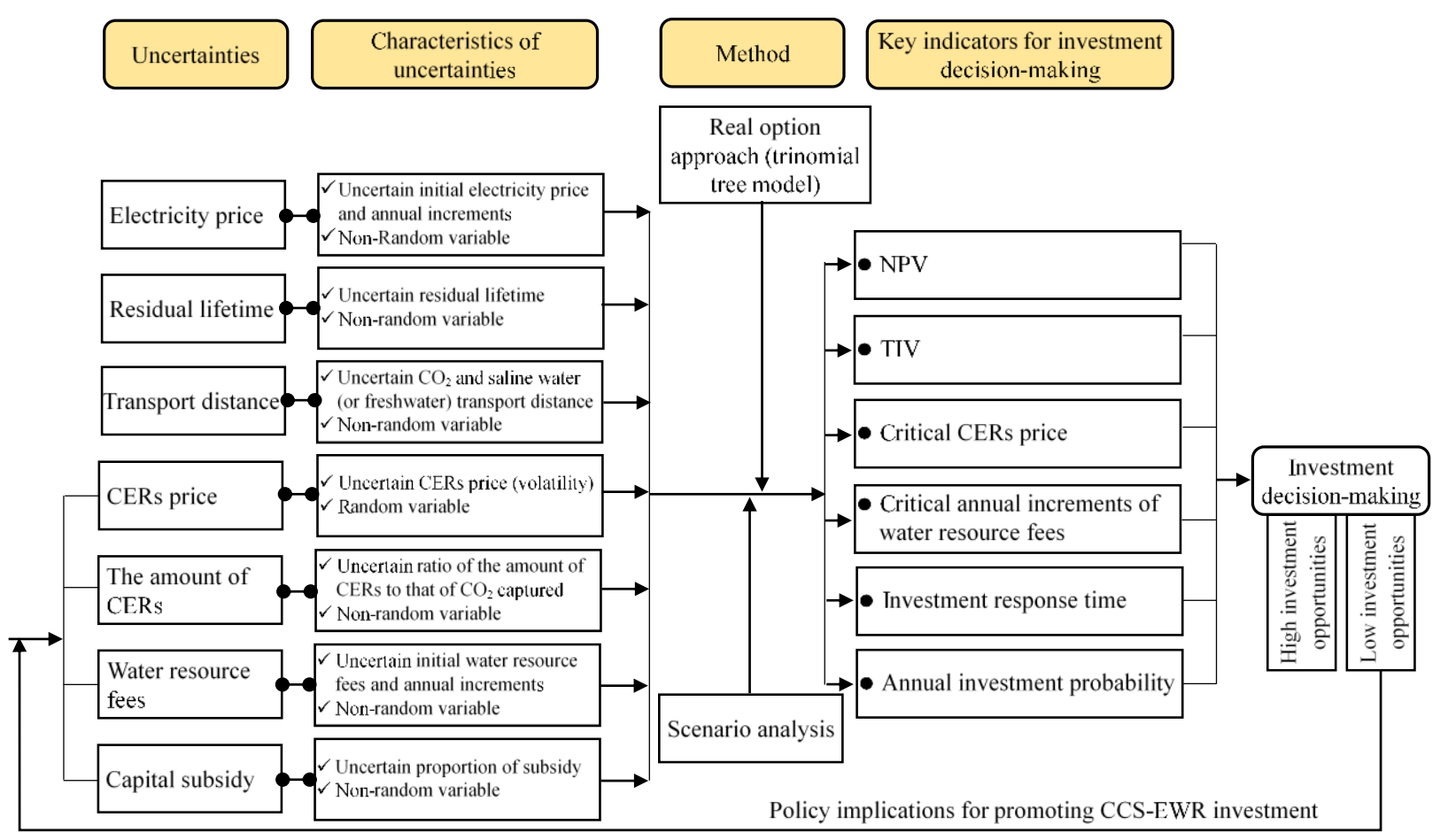

Fig. 1. Research framework.

\subsection{Research system boundary}

It is necessary to define the system boundary while exploring the economies of CCS-EWR, CCS and EWR, respectively. The evaluation object of this study is the CCS-EWR project, which does not include direct coal liquefaction plant. The benefit of freshwater after saline water desalination tends to be due to the existence of EWR. CCS-EWR includes nine technical links, where the main problem beneath the boundary defining CCS and EWR is the ascription of deep saline water extraction. From EWR's 
perspective, the saline water extraction wells are the prerequisite for EWR. However, even without saline water desalination and utilization, saline water extraction wells are also needed to improve reservoir storage capacity and prevent the $\mathrm{CO}_{2}$ leakage from excessive reservoir pressure. Therefore, saline water extraction wells are classified into CCS (Fig. 2).

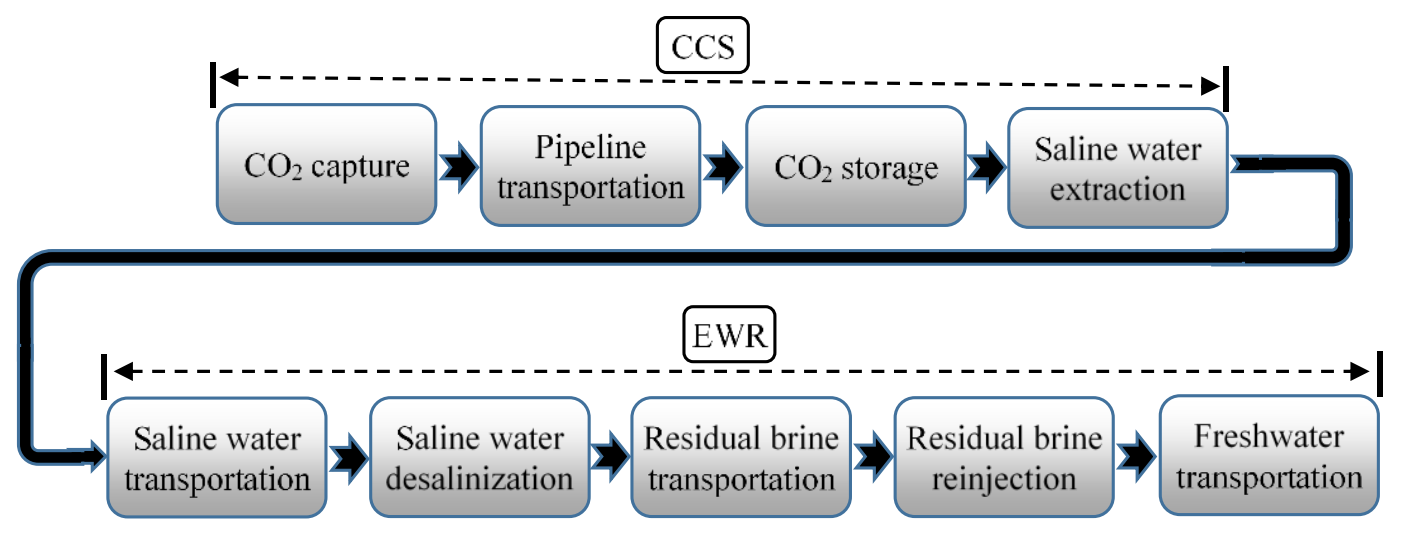

Fig. 2. Boundary definition of CCS and EWR.

\section{Method}

\subsection{NPV}

The cash flow of the entire CCS-EWR process contains investment costs and benefits. Total investment costs (cash outflow) contain capital costs, energy costs, and operating and maintenance costs, etc. The revenue (cash inflow) is composed of the profits from CERs, savings on freshwater production costs, exemption from water resource fees, and capital subsidies.

$$
\begin{aligned}
N b= & A_{C E R s} \cdot P_{C E R_{s}}+A_{R F} \cdot\left(F_{w}+W_{f}\right)-\left(1-k_{1}\right) \cdot\left(C_{c c}+C_{c t}+C_{c s}+C_{e w}\right)-\left(1-k_{2}\right) \cdot \\
& \left(C_{s t}+C_{d}+C_{r b t}+C_{r w}+C_{f t}\right)-A_{C} \cdot\left(C_{c c}^{o \& m}+C_{c t}^{o \& m}+C_{c s}^{o \& m}+C_{e}+C_{w}\right)- \\
& A_{S W} \cdot\left(C_{e w}^{o \& m}+C_{s t}^{o \& m}\right)-A_{R B} \cdot\left(C_{r b t}^{o \& m}+C_{r w}^{o \& m}\right)-A_{R F} \cdot\left(C_{d}^{o \& m}+C_{f t}^{o \& m}\right)
\end{aligned}
$$

where $N b$ denotes net benefits, $(\mathrm{CNY}) ; A_{C}$ is the amount of $\mathrm{CO}_{2}$ captured, (tons); $A_{\text {CERs }}$ is the amount of CERs, (tons); $P_{C E R s}$ is the CERs price, (CNY/ton); $A_{R F}$ denotes the amount of recovered freshwater after desalination, (tons); $F_{w}$ is the freshwater production cost of waterworks, (CNY/ton); $W_{f}$ denotes the water resource fees, (CNY/ton); $A_{S W}$ is the amount of extracted saline water, (tons); $A_{R B}$ is the amount of residual brine, (tons); $C_{c c}$ denotes the capital cost of $\mathrm{CO}_{2}$ capture, $(\mathrm{CNY}) ; C_{c t}$ is the capital cost of $\mathrm{CO}_{2}$ transportation, $(\mathrm{CNY}) ; C_{c s}$ is the capital cost of $\mathrm{CO}_{2}$ storage, some of which is site screening and evaluation cost, $(\mathrm{CNY}) ; C_{e w}$ is the capital cost of extraction well, $(\mathrm{CNY}) ; C_{s t}$ is the capital cost of 
saline water transportation, $(\mathrm{CNY}) ; C_{d}$ is the capital cost of desalination plant, $(\mathrm{CNY}) ; C_{r b t}$ is the capital cost of residual brine transportation, $(\mathrm{CNY}) ; C_{r w}$ is the capital cost of reinjection well, $(\mathrm{CNY})$; $C_{f t}$ is the capital cost of freshwater transportation, $(\mathrm{CNY}) ; C_{c c}^{o \& m}$ is the operating and maintenance cost of $\mathrm{CO}_{2}$ capture, $\left(\mathrm{CNY} /\right.$ ton); $C_{c t}^{o \& m}$ is the operating and maintenance cost of $\mathrm{CO}_{2}$ transportation, (CNY/ton); $C_{c s}^{o \& m}$ is the operating and maintenance cost of $\mathrm{CO}_{2}$ storage, $\left(\mathrm{CNY} /\right.$ ton); $C_{e}$ is the energy cost of CCS-EWR, (CNY/kWh (Chinese Yuan per kilowatt hour)); $C_{w}$ is the freshwater cost of CCS-EWR, (CNY/ton); $C_{e w}^{o \& m}$ is the operating and maintenance cost of saline water extraction, (CNY/ton); $C_{s t}^{o \& m}$ is the operating and maintenance cost of saline water transportation, (CNY/ton); $C_{r b t}^{o \& m}$ is the operating and maintenance cost of residual brine transportation, (CNY/ton); $C_{r w}^{o \& m}$ is the operating and maintenance cost of reinjection, $(\mathrm{CNY} /$ ton $) ; C_{d}^{o \& m}$ is the operating and maintenance cost of saline water desalination, which includes energy cost and freshwater cost, (CNY/ton); $C_{f t}^{o \& m}$ is the operating and maintenance cost of freshwater transportation, (CNY/ton); $k_{1}$ is the subsidy proportion of CCS capital costs; and $k_{2}$ is the subsidy proportion of EWR capital costs. The high pressure of the reservoir fluid serves as the driving pressure for the reverse osmosis process in the absence of pressurized equipment (Bourcier et al., 2011; Wolery et al., 2009).

The certification of emission reduction is one of the key tasks in CERs trading. CERs are calculated by equation Eq. (2):

$$
A_{C E R s}=A_{C} \cdot \eta=\pi \cdot E_{\mathrm{c}} \cdot \eta
$$

where $E_{\mathrm{c}}$ is the annual $\mathrm{CO}_{2}$ emissions, (tons/year); $\pi$ is the capture rate; and $\eta$ is the certified rate.

Previous studies have mainly referred to the CERs price of the European carbon market, which follows the rule of geometric Brownian motion (Fuss et al., 2008; Insley, 2003; Zhou et al., 2010). We assume that the CERs price varies randomly following the rule of geometric Brownian motion in this study:

$$
d P_{C E R s}=\mu P_{C E R s} d t+\sigma P_{C E R s} d w
$$

where $\mu$ and $\sigma$ are the CERs price drift rate and volatility, respectively; and $d w$ is the independent increments of a standard Wiener process.

The amount of recovered freshwater is affected by the displacement ratio of $\mathrm{CO}_{2}$ and saline water and the recovery rate in the desalination process. In this study, the displacement ratio and recovery rate are assumed to be constant.

$$
\left\{\begin{array}{l}
A_{S W}=A_{C} \cdot d r \\
A_{R F}=A_{S W} \cdot \omega
\end{array}\right.
$$


where $d r$ denotes the displacement ratio of $\mathrm{CO}_{2}$ and saline water, (tons/ton $\mathrm{CO}_{2}$ ); $\omega$ denotes the recovery rate in the desalination process.

$\mathrm{CO}_{2}$ capture projects at high concentration $\mathrm{CO}_{2}$ emission sources are already widespread (IPCC, 2005). Therefore, the cost reduction potential of CCS-EWR projects in direct coal liquefaction plants is small. Therefore, this paper leaves the technological progress out of account. This study only considers the energy consumption for $\mathrm{CO}_{2}$ capture, and the other technical links basically do not consume energy. In addition, the $\mathrm{CO}_{2}$ concentration in the tail gas of direct coal liquefaction plant is high, and only the electricity is consumed by $\mathrm{CO}_{2}$ capture (Xiang et al., 2014).

$$
\begin{gathered}
W_{f \cdot t}=W_{f \cdot 0}+W_{a i} t \\
E_{p \cdot t}=E_{p \cdot 0}+E_{a i} t
\end{gathered}
$$

where $W_{f . t}$ denotes the water resource fees in year t, (CNY/ton); $W_{f .0}$ denotes the initial water resource fees, (CNY/ton); and $W_{a i}$ denotes the annual increase in the water resource fees, (CNY/ton); $E_{p . t}$ denotes the electricity prices in year $\mathrm{t},(\mathrm{CNY} / \mathrm{kWh}) ; E_{p .0}$ denotes the initial electricity prices, $(\mathrm{CNY} / \mathrm{kWh})$; and $E_{a i}$ denotes the annual increase in the electricity prices, (CNY/kWh).

Here, we assume that the direct coal liquefaction plants start operating at time $\tau_{0}$ and end at time $\tau_{2}$; CCS-EWR would be constructed at time $\tau_{1}\left(\tau_{0} \leq \tau_{1} \leq \tau_{2}-1\right)$, start operating at time $t=\tau_{1}+1$, and end at time $\tau_{2}$. In this paper, $\gamma_{0}$ is the discount rate, and it is assumed that CCS-EWR equipment has no residual value. The NPV of CCS-EWR is calculated as follows:

$$
\begin{aligned}
N P V_{\tau_{1}}= & E_{\mathrm{c}} \cdot \pi \cdot\left(\eta \cdot P_{C E R s}+d r \cdot \omega \cdot\left(F_{w}+W_{f \cdot 0}\right)-\left(C_{c c}^{o \& m}+C_{c t}^{o \& m}+C_{c s}^{o \& m}+W C \cdot W_{f .0}+E C \cdot E_{p .0}\right)-\right. \\
& \left.d r \cdot\left(C_{e w}^{o \& m}+C_{s t}^{o \& m}\right)-d r \cdot(1-\omega) \cdot\left(C_{r b t}^{o \& m}+C_{r w}^{o \& m}\right)-d r \cdot \omega \cdot\left(C_{d}^{o \& m}+C_{f t}^{o \& m}\right)\right) \cdot \frac{\left(1+\gamma_{0}\right)^{\tau_{2}-\tau_{1}}-1}{\gamma_{0}\left(1+\gamma_{0}\right)^{\tau_{2}-\tau_{1}}}+ \\
& \left(\left(E_{\mathrm{c}} \cdot \pi \cdot d r \cdot \omega-W C\right) \cdot W_{a i}-E C \cdot E_{a i}\right) \cdot \frac{\left(1+\gamma_{0}\right)^{\tau_{2}-\tau_{1}+1}-\left(1+\gamma_{0}+\tau_{2} \gamma_{0}-\tau_{1} \gamma_{0}\right)}{\gamma_{0}^{2}\left(1+\gamma_{0}\right)^{\tau_{2}-\tau_{1}}}- \\
& \left(\left(1-k_{1}\right)\left(C_{c c .0}+C_{c t}+C_{c s}+C_{e w}\right)-\left(1-k_{2}\right)\left(C_{s t}+C_{d}+C_{r b t}+C_{r w}+C_{f t}\right)\right) \cdot(1+\gamma)^{\tau_{1}-1}
\end{aligned}
$$

where $W C$ is the water consumption of CCS-EWR, (tons/ton); EC is the energy consumption of CCS-EWR, (kWh/ton).

\subsection{TIV}

A trinomial tree model is constructed to assess the investment value of CCS-EWR under the option to defer. Here, the CERs price will increase to $P_{C E R S} \cdot u$, decrease to $P_{C E R s} \cdot d$, or remain unchanged $(u \cdot d=1, u>1>d>0)$, with probabilities $P_{u}, P_{m}$, and $P_{d}$ deduced by a risk-neutral theory (Yuen and 
Yang, 2010; Zhang et al., 2014). Moreover, we assume that the volatility $\sigma$ and the risk-free interest rate $\gamma$ are constant.

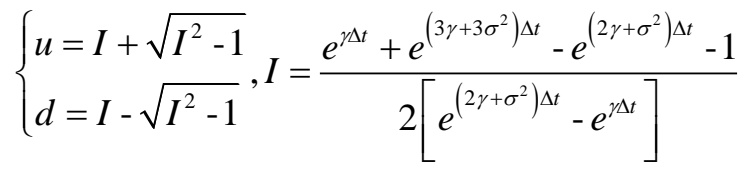

$$
\begin{aligned}
& \left\{\begin{array}{l}
P_{u}=\frac{e^{\gamma \Delta t}(1+d)-e^{\left(2 \gamma+\sigma^{2}\right) \Delta t}-d}{(d-u)(u-1)} \\
P_{m}=\frac{e^{\gamma \Delta t}(u+d)-e^{\left(2 \gamma+\sigma^{2}\right) \Delta t}-1}{(1-d)(u-1)} \\
P_{d}=\frac{e^{\gamma \Delta t}(1+u)-e^{\left(2 \gamma+\sigma^{2}\right) \Delta t}-u}{(1-d)(d-u)}
\end{array}\right.
\end{aligned}
$$

The NPV during the period of deferred investments can be calculated according to Eq. (7) as the CERs price scatters in the trinomial tree model. However, the NPV of each node is not always positive. From the perspective of the option to defer, investors have the right to give up investments in node $(i, j)$ with a negative $N P V_{(i, j)}, \mathrm{j}$ and $\mathrm{i}$ in the node $(\mathrm{i}, \mathrm{j})$ represent the $\mathrm{j}$-th year of the decision making and the top-down i-th node in the trinomial model, as shown in Fig. A1 of the Appendix A. Then, the investment value $I V_{(i, j)}$ is 0 , and $I V_{(i, j)}$ equals $N P V_{(i, j)}$ when it is positive, as shown in Eq. (10). In addition, investors may still re-evaluate the CCS-EWR investment value at each node with a positive NPV and then decide to defer or invest immediately. Thus, $T I V_{(i, j)}$ is recalculated step by step backward from the last step to the current step, as shown in Eq. (11).

$$
\begin{aligned}
& I V_{(i, j)}=\max \left(N P V_{(i, j)}, 0\right) \\
& T I V_{(i, j)}=\max \left(I V_{(i, j)},\left[P_{u} \cdot N P V_{(i, j+1)}+P_{m} \cdot N P V_{(i+1, j+1)}+P_{d} \cdot N P V_{(i+2, j+1)}\right] \cdot e^{-\gamma \Delta t}\right)
\end{aligned}
$$

\subsection{The investment decision rule}

The investment rule is the basis for investment decision making (Zhang et al., 2014). There are 4 possibilities for investment decisions based on the real option approach: 1) investors should abandon CCS-EWR investments when they are still unable to achieve profitability even with flexible management and decision making; 2) investors should invest immediately when the $N P V_{(i, j)}$ is positive and $\operatorname{ROV} V_{(i, j)}$ is $0 ; 3$ ) investors should defer the investments when the $N P V_{(i, j)}$ is negative and $\operatorname{TIV}_{(i, j)}$ is positive; and 4) investors should defer the investments when both $N P V_{(i, j)}$ and $R O V_{(i, j)}$ are positive. Detailed 
decision rules are shown in Table 1.

Table 1 CCS-EWR investment decision rules under the real option approach

\begin{tabular}{clll}
\hline Numbers & $N P V_{(i, j)}$ & $T I V_{(i, j)}$ & Decisions \\
\hline 1$)$ & $N P V_{(i, j)} \leq 0$ & $T I V_{(i, j)}=0$ & Abandon investments \\
2) & $N P V_{(i, j)}>0$ & $T I V_{(i, j)}=N P V_{(i, j)}$ & Invest immediately \\
$3)$ & $N P V_{(i, j)} \leq 0$ & $T I V_{(i, j)}>0$ & Defer investments \\
$4)$ & $N P V_{(i, j)}>0$ & $T I V_{(i, j)}>N P V_{(i, j)}$ & Defer investments \\
\hline
\end{tabular}

\subsection{Annual investment probabilities}

The annual investment probabilities can help investors understand the investment information in the period of the option to defer and effectively guide investment decision making. According to the investment decision rule under the real option approach, the determination of investment probabilities can be divided into three steps (Zhang et al., 2014), as defined by Eq. (12): 1) the probabilities $\chi_{i, j}$ can be calculated according to the probabilities of nodes connected to node $(i, j)$ in the previous year; 2 ) investors make investment decisions in node $(\mathrm{i}, \mathrm{j})$ based on $N P V_{\mathrm{i}, j}$ and $T I V_{i, j}$; if the investment in the CCS-EWR project occurs immediately in node $(\mathrm{i}, \mathrm{j})$, the investment probability is $\chi_{i, j}\left(\chi_{i, j}^{2}\right)$; otherwise it is $0\left(\chi_{i, j}^{1}\right)$; and 3) the annual investment probability $\chi_{j}$ is the sum of $\chi_{i, j}^{2}$.

$$
\left\{\begin{array}{l}
\chi_{i, j}=p_{u} \cdot \chi_{i-2, j-1}+p_{m} \cdot \chi_{i-1, j-1}+p_{d} \cdot \chi_{i, j-1}, \chi_{1,1}=1 \\
\chi_{i, j}^{1}=0, \text { when } N P V_{(i, j)} \leq 0 \text { or } T I V_{(i, j)}>N P V_{(i, j)}>0 \\
\chi_{i, j}^{2}=\chi_{i, j}, \text { when } \operatorname{TIV} V_{(i, j)}=N P V_{(i, j)}>0 \\
\chi_{j}=\sum \chi_{i, j}^{2}
\end{array}\right.
$$

\section{Research case and data}

\subsection{Research case}

Ordos is an important production base of coal power and the coal chemical in China, with an installed gross capacity of thermal power plants of 17.7 gigawatts and a production capacity of coal chemical capacity of 12.13 Mtons (million tons) in 2015 (GOPGO, 2017). The Shenhua direct coal liquefaction plant uses high-quality raw coal from Shenfu-Dongsheng Coalfield as raw material to produce diesel oil, naphtha and other products (Wu, 2013). The total design capacity of Shenhua direct 
coal liquefaction plant is 5 Mtons/year. The first production line was put into operation in 2008, with a capacity of 1.08 Mtons/year, which is the only commercial direct coal liquefaction production line in the world (Wu, 2013).

The Shenhua Group CCS project, where the capture source and storage locations are $17 \mathrm{~km}$ apart, as shown in Fig. 3, in Ordos, is China's first full-chain $\mathrm{CO}_{2}$ saline aquifer storage project. The project is designed such that $\mathrm{CO}_{2}$ is derived from a low-temperature methanol washing unit in a coal-based hydrogen preparation device, with a capture and storage capacity of 100 ktons/year. The project successfully injected supercritical $\mathrm{CO}_{2}$ into the brine aquifer in 2011 and completed the demonstration target in April 2015.
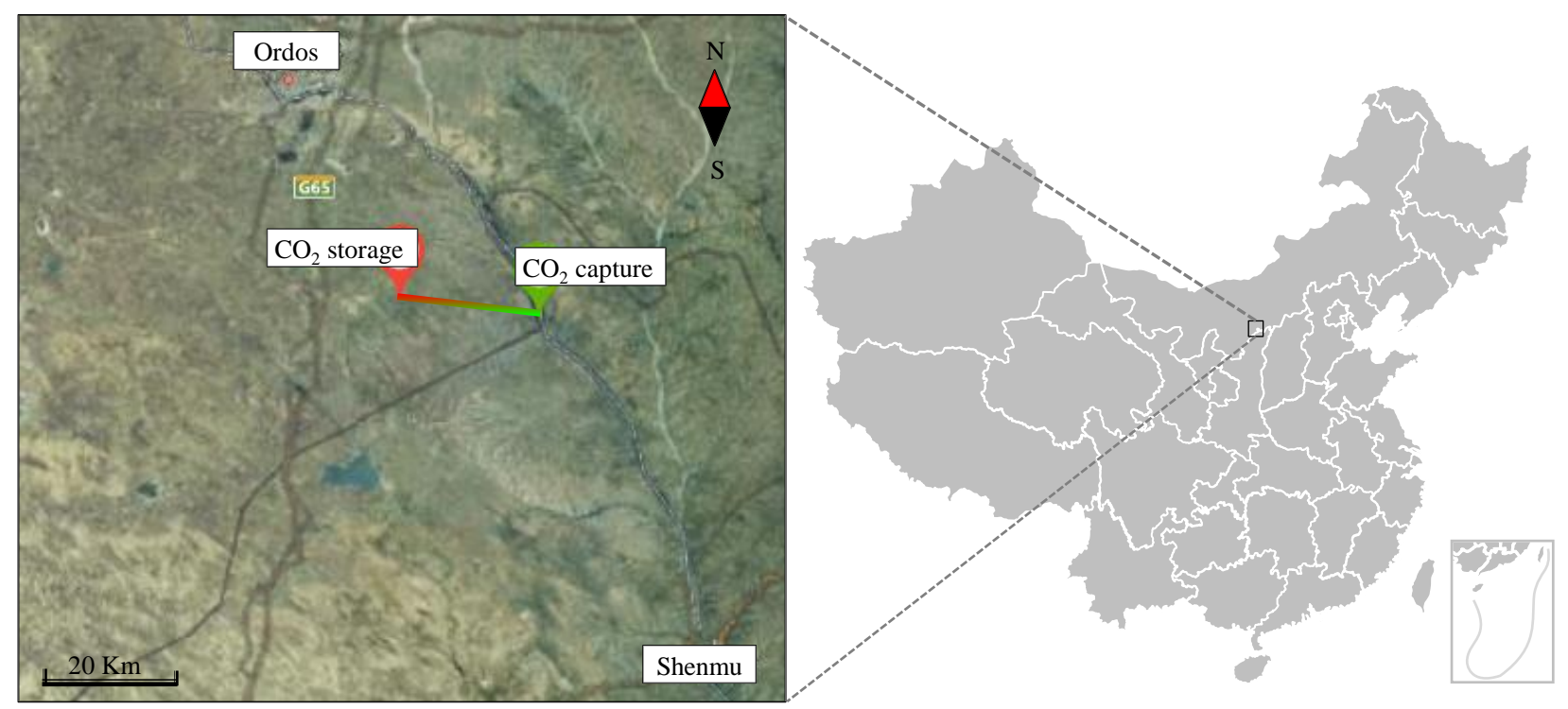

Fig. 3. Diagram of the location of the Shenhua CCS project.

Compared with Shenhua CCS demonstration project, the case selected in this study is larger in capture scale. In addition, the direct coal liquefaction plant in the case is newly built. $\mathrm{CO}_{2}$ in this study also comes from a low-temperature methanol washing unit, with emissions of 2.96 Mtons/year and a volume fraction of $87.6 \%$, as shown in Table 2. The specific technical parameters are shown in Fig. 4 (refer to oil and gas well layout) and Table 3.

Table $2 \mathrm{CO}_{2}$ emissions in each unit of direct coal liquefaction plants, referring to $\mathrm{Wu}(2013)$.

\begin{tabular}{cccc}
\hline $\mathrm{CO}_{2}$ resource & $\begin{array}{c}\text { Emissions } \\
\text { (Mtons/year) }\end{array}$ & $\begin{array}{c}\mathrm{CO}_{2} \text { concentration } \\
\text { (Volume fraction, \%) }\end{array}$ & $\begin{array}{c}\text { Proportion of total } \\
\text { emissions (\%) }\end{array}$ \\
\hline Low-temperature & 2.96 & 87.6 & 48.0 \\
\hline
\end{tabular}




\begin{tabular}{lccc}
\hline Methanol washing unit & & & \\
Boiler & 2.56 & 15.1 & 41.6 \\
Other & 0.64 & $/$ & 10.4 \\
Total & 6.16 & $/$ & 100 \\
\hline
\end{tabular}

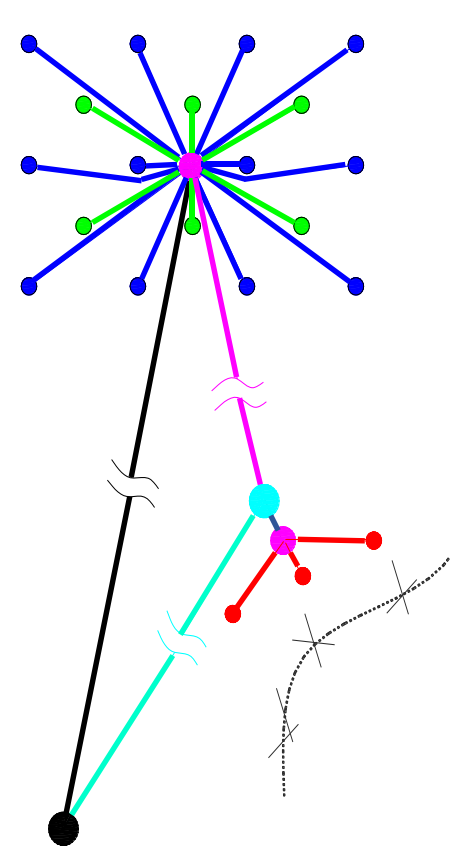

- Branch pipelines $\left(\mathrm{CO}_{2}, 3.5 \mathrm{~km}, 7.8 \mathrm{~km}, 10.5 \mathrm{~km}, 12.6 \mathrm{~km}\right)$

- Branch pipelines (saline water, $3.5 \mathrm{~km}, 7.8 \mathrm{~km}$ )

- Branch pipelines (residual, $0 \mathrm{~km}, 5 \mathrm{~km}$ )

- Main pipeline (saline water, $10 \mathrm{~km}$ )

- Main pipeline (freshwater, $10 \mathrm{~km}$ )

- Main pipeline $\left(\mathrm{CO}_{2}, 20 \mathrm{~km}\right)$

- Main pipeline (residual, $5 \mathrm{~km}$ )

Fault

- $\mathrm{CO}_{2}$ injection wells

- Saline water extraction wells

- Residual brine reinjection wells

- Distribution point

- Direct coal liquefaction

Saline water desalination

Fig. 4. Layout diagram of technical joints and the pipeline of CCS-EWR.

Table 3 Parameters and description of the technical links of CCS-EWR.

\begin{tabular}{ll}
\hline Technical links & Parameters (pipeline diameter refers to data from McCollum and Ogden (2006)) \\
\hline $\mathrm{CO}_{2}$ capture & Capture rate is $80 \%$. \\
& The main transportation pipeline length is $20 \mathrm{~km}$, with a transportation capacity of \\
& 6485 tons/day and a diameter of 10 inches. The total length of the 12 branch \\
$\mathrm{CO}_{2}$ & pipelines is $102.6 \mathrm{~km}$, with a single pipeline transportation capacity of 548 tons/day \\
transportation & and a diameter of 3.5 inches. In addition, there is no booster station (McCollum and \\
& Ogden, 2006). \\
& The number of $\mathrm{CO}_{2}$ injection wells is affected by geological conditions of the saline \\
& aquifer in the Ordos Basin. This project will require 12 wells (Dahowski et al., 2012), \\
& with a single well injection's capacity of 0.2 Mtons/year and a depth of 2000 m
\end{tabular}




\begin{tabular}{|c|c|}
\hline & 014). \\
\hline $\begin{array}{l}\text { Saline water } \\
\text { extraction }\end{array}$ & $\begin{array}{l}6 \text { extraction wells are used to extract saline water, and the construction requirements } \\
\text { are consistent with those of the } \mathrm{CO}_{2} \text { injection well. Moreover, the distance between } \\
\text { the } \mathrm{CO}_{2} \text { injection well and the saline water extraction well is } 5 \mathrm{~km} \text {. }\end{array}$ \\
\hline $\begin{array}{l}\text { Saline water } \\
\text { transportation }\end{array}$ & $\begin{array}{l}\text { The pipeline construction requirements are consistent with those of the } \mathrm{CO}_{2} \text { transport } \\
\text { pipeline. The main transportation pipeline length is } 10 \mathrm{~km} \text {, with a transportation } \\
\text { capacity of } 6485 \text { tons/day and a diameter of } 10 \text { inches. The total length of the } 6 \\
\text { branch pipelines is } 38.2 \mathrm{~km} \text {, with a single pipeline transportation capacity of } 1096 \\
\text { tons/day and a diameter of } 5 \text { inches. In addition, there is no booster station. }\end{array}$ \\
\hline $\begin{array}{l}\text { Saline water } \\
\text { desalination }\end{array}$ & $\begin{array}{l}\text { The reverse osmosis method is selected to desalinate saline water with the salinity of } \\
10 \text { g/L-50 g/L TDS (Klapperich et al., 2013; Li et al., 2015; Wolery et al., 2009). }\end{array}$ \\
\hline $\begin{array}{l}\text { Residual brine } \\
\text { transportation }\end{array}$ & $\begin{array}{l}\text { The pipeline construction requirements are consistent with those of the } \mathrm{CO}_{2} \text { transport } \\
\text { pipeline. The main transportation pipeline's length is } 5 \mathrm{~km} \text {, with a transportation } \\
\text { capacity of } 3567 \text { tons/day and a diameter of } 7.5 \text { inches. The total length of the branch } \\
\text { pipeline is } 10 \mathrm{~km} \text {, with a single pipeline transportation capacity of } 1189 \text { tons/day and } \\
\text { a diameter of } 5 \text { inches. In addition, there is no booster station. }\end{array}$ \\
\hline $\begin{array}{l}\text { Residual brine } \\
\text { reinjection }\end{array}$ & $\begin{array}{l}\text { The reinjection wells are located between the } \mathrm{CO}_{2} \text { storage area and faults. The } \\
\text { reservoir pressure increases during the residual brine reinjection to prevent the } \\
\text { migration and leakage of } \mathrm{CO}_{2} \text {. Moreover, } 3 \text { extraction wells are used for reinjection, } \\
\text { and the construction requirements are consistent with those of the } \mathrm{CO}_{2} \text { injection well. }\end{array}$ \\
\hline $\begin{array}{l}\text { Freshwater } \\
\text { transportation }\end{array}$ & $\begin{array}{l}\text { Three plastic pipelines of lengths of } 10 \mathrm{~km} \text { and diameters of } 150 \mathrm{~mm} \text { are used to } \\
\text { transport freshwater, because of the low pressure (Zhai et al., 2016). }\end{array}$ \\
\hline
\end{tabular}

\subsection{Parameters and data}

We assume that the service life of a new direct coal liquefaction plant is 30 years from 2019-2048. Moreover, the investment evaluation step length is 1 year. In addition, all costs have been normalized to real 2018 China CNY. First, the historical exchange rate is used to convert data expressed in different currencies into China CNY. Then, $\mathrm{CO}_{2}$ capture and desalination costs are updated based on chemical engineering plant cost index (Fig. 5); transportation costs of $\mathrm{CO}_{2}$, saline water, freshwater and residual brine are updated based on oil pipeline index (Fig. 5); storage costs of $\mathrm{CO}_{2}$, extraction costs of saline water and reinjection costs of residual brine are updated based on U.S. Bureau of Labor Statistics producer price index for drilling oil, gas, dry, or service wells (Fig. 5). Because China's (commodity) prices and labour costs are lower than those in the US, Canada, and other developed countries, a conversion factor of 0.8 is 
used to convert costs between China and developed countries (Renner, 2014).

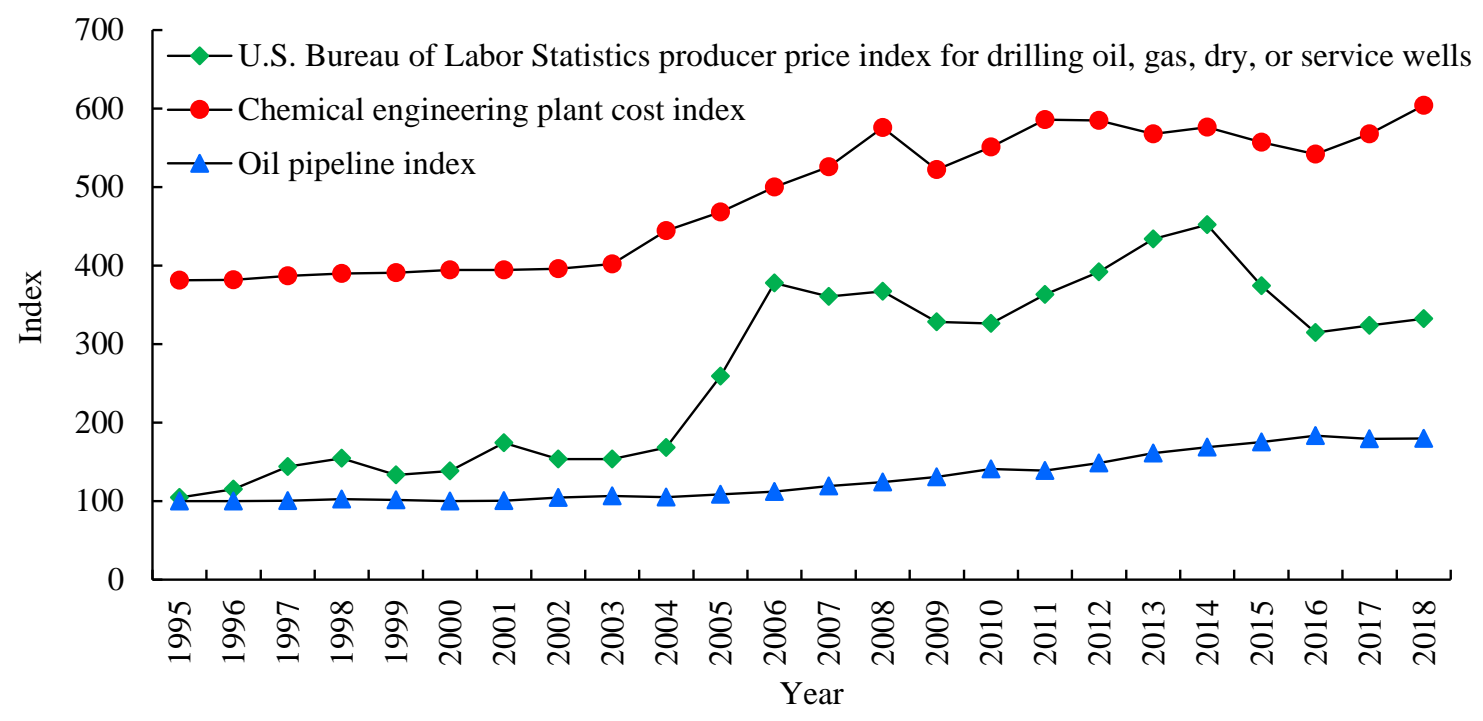

Fig. 5 The chemical engineering plant cost index (CEECPIP, 2019; EDOC, 2017; Leeson et al., 2017;

Vatavuk, 2002), oil pipeline index (FERC, 2018) and U.S. Bureau of Labor Statistics producer price index for drilling oil, gas, dry, or service wells (U.S. BLS, 2018).

\subsubsection{Parameters and data for various costs of the CCS}

$\mathrm{CO}_{2}$ capture. The concentration of $\mathrm{CO}_{2}$ in feed gas from direct coal liquefaction plants and coal to olefins plants is almost the same (Wu, 2013); thus, the capital investment (392 MCNY/Mton) and energy consumption (98.5 kWh/ton) (Xiang et al., 2014) of $\mathrm{CO}_{2}$ capture can also be considered the same. In this study, the initial electricity price is $0.47 \mathrm{CNY} / \mathrm{kWh}$ (IMDRC, 2015), and the comprehensive initial water price includes water resource fees, sewage disposal fees and freshwater production costs, is $10.9 \mathrm{CNY} /$ ton (ODRC, 2017; PCEPA, 2009; PGIMAR, 2014). In addition, the water consumption of CCS-EWR is 1 tons/ton $\mathrm{CO}_{2}$, considering desalted water of 0.45 tons/ton $\mathrm{CO}_{2}$, circulating cooling water loss of 0.43 tons/ton $\mathrm{CO}_{2}$, domestic water, etc. $(\mathrm{Wu}, 2013)$. Based on the historical price trend and the consideration of low-carbon technology investment, it is expected that China's electricity price will continue to rise in the future, with an annual increment of $0.01 \mathrm{CNY} / \mathrm{kWh}$ (Zhou et al., 2010). In addition, the annual increase in water resources fees in Ordos is 0.75 CNY/ton (EHBWRMO, 2012; PGIMAR, 2014).

$\mathrm{CO}_{2}$ transportation. Ordos is located in northwestern China, and its geographical environment is dominated by hills, plateaus, and deserts (Ordos, 2018). Therefore, the Ordos geographical environment is assumed to be stony desert. The annual operating and maintenance costs are $2.5 \%$ of the capital costs. 
Referring to the models constructed by McCollum and Ogden (2006), we calculate the capital costs and operating and maintenance costs.

$\mathrm{CO}_{2}$ storage and saline water extraction. $\mathrm{CO}_{2}$ reservoirs are generally a low permeability rock formation in which porosity $(1 \%-20 \%)$ and permeability $(<300$ millidarcy) vary greatly (Fang and Li, 2014). In this paper, the permeability is 10 millidarcy. In this study, the displacement ratio of $\mathrm{CO}_{2}$ and saline water is 1 tons/ton $\mathrm{CO}_{2}$. The capital cost and operating and maintenance costs of $\mathrm{CO}_{2}$ injection wells and saline water extraction wells are calculated based on models constructed by McCollum and Ogden (2006).

Table 4 Parameters and data for various costs of the CCS

\begin{tabular}{|c|c|c|c|}
\hline Links & Parameters & Value & Data sources \\
\hline \multirow{10}{*}{$\mathrm{CO}_{2}$ capture } & $\mathrm{CO}_{2}$ emissions (Mtons/year) & 2.96 & \multirow[t]{3}{*}{$(\mathrm{Wu}, 2013)$} \\
\hline & Capture rate & $80 \%$ & \\
\hline & Capital costs (MCNY) & 930 & \\
\hline & Operating and maintenance costs (CNY/ton) & 10.48 & \multirow[t]{2}{*}{ (Xiang et al., 2014) } \\
\hline & Energy (electricity) consumption (kWh/ton) & 98.5 & \\
\hline & Initial electricity price (CNY/kWh) & 0.47 & (IMDRC, 2015) \\
\hline & Annual increase in the electricity prices $(\mathrm{CNY} / \mathrm{kWh})$ & 0.01 & (Zhou et al., 2010) \\
\hline & Water consumption (tons/ton) & 1 & (Wu, 2013) \\
\hline & Comprehensive initial water price & 10.9 & $\begin{array}{l}\text { (ODRC, 2017; PCEPA, } \\
\text { 2009; PGIMAR, 2014) }\end{array}$ \\
\hline & $\begin{array}{l}\text { Annual increase in the water resource fees } \\
\text { (CNY/ton) }\end{array}$ & 0.75 & $\begin{array}{l}\text { (EHBWRMO, 2012; } \\
\text { PGIMAR, 2014) }\end{array}$ \\
\hline \multirow{4}{*}{$\begin{array}{l}\mathrm{CO}_{2} \\
\text { transportation }\end{array}$} & Main pipeline capital costs (MCNY) & 58 & \\
\hline & $\begin{array}{l}\text { Main pipeline operating and maintenance costs } \\
\text { (CNY/ton) }\end{array}$ & 0.61 & (McCollum \\
\hline & Branch pipeline capital costs (MCNY) & 122 & \multirow[t]{2}{*}{ Ogden, 2006) } \\
\hline & $\begin{array}{l}\text { Branch pipeline operating and maintenance costs } \\
\text { (CNY/ton) }\end{array}$ & 1.29 & \\
\hline $\begin{array}{l}\mathrm{CO}_{2} \text { storage } \\
\text { and saline }\end{array}$ & $\begin{array}{l}\text { Displacement ratio of } \mathrm{CO}_{2} \text { and saline water (tons/ton } \\
\mathrm{CO}_{2} \text { ) }\end{array}$ & 1 & (Fang and Li, 2014) \\
\hline water & Capital costs of $\mathrm{CO}_{2}$ storage (MCNY) & 57.7 & (McCollum \\
\hline extraction & Operating and maintenance costs of $\mathrm{CO}_{2}$ storage & 1.90 & Ogden, 2006) \\
\hline
\end{tabular}


(CNY/ton)

Capital costs of saline water extraction (MCNY)

20.2

Operating and maintenance costs of saline water

extraction $(\mathrm{CNY} /$ ton $)$

0.60

\subsubsection{Parameters and data for various costs of the EWR}

Saline water desalination. Reverse osmosis plants can be built and operated for approximately half of the costs of seawater desalination. Capital costs refer to data from Wolery et al. (2009). The total costs of desalination in China ranges from 4-7 CNY/ton, of which the operating and maintenance costs (including energy cost and freshwater cost) accounts for approximately 70\% (Li and Wei, 2013; Ziolkowska, 2015).

Saline water transportation, residual brine reinjection, residual brine transportation. Referring to the models constructed by McCollum and Ogden (2006), we calculate the capital costs and operating and maintenance costs.

Freshwater transportation. Referring to the data and accounting methods provided by Zhai et al. (2016), we calculate the capital costs and operating and maintenance costs.

Table 5 Parameters and data for various costs of the EWR

\begin{tabular}{llll}
\hline Links & Parameters & Value & Data sources \\
\hline & Main pipeline capital costs (MCNY) & 26.5 & \\
& Main pipeline operating and maintenance & 0.28 & (McCollum and Ogden, \\
Saline water & costs (CNY/ton) & & 2006) \\
transportation & Branch pipeline capital costs (MCNY) & 31.1 & \\
& Branch pipeline operating and maintenance & 0.33 & \\
& costs (CNY/ton) & 0.45 & (Wolery et al., 2009) \\
Saline water & Capital costs (MCNY) & 41.2 & (Li and Wei, 2013; Wolery \\
desalination & Operating and maintenance costs, (CNY/ton) & 2.28 & $\begin{array}{l}\text { et al., 2009; Ziolkowska, } \\
\text { Residual }\end{array}$ \\
$\begin{array}{l}\text { Capital costs (MCNY) } \\
\text { brine }\end{array}$ & Operating and maintenance costs, (CNY/ton) & 1.02 & 2006)
\end{tabular}




\begin{tabular}{|c|c|c|c|}
\hline \multirow{4}{*}{$\begin{array}{l}\text { Residual } \\
\text { brine } \\
\text { transportation }\end{array}$} & Main pipeline capital costs (MCNY) & 21.5 & \multirow{4}{*}{$\begin{array}{l}\text { (McCollum and Ogden, } \\
\text { 2006) }\end{array}$} \\
\hline & $\begin{array}{l}\text { Main pipeline operating and maintenance } \\
\text { costs (CNY/ton) }\end{array}$ & 0.41 & \\
\hline & Branch pipeline capital costs ( $\mathrm{MCNY}$ ) & 13.4 & \\
\hline & $\begin{array}{l}\text { Branch pipeline operating and maintenance } \\
\text { costs (CNY/ton) }\end{array}$ & 0.26 & \\
\hline Freshwater & Capital costs (MCNY) & 3.1 & \multirow{2}{*}{ (Zhai et al., 2016) } \\
\hline transportation & Operation and maintenance costs (CNY/ton) & 0.29 & \\
\hline
\end{tabular}

\subsubsection{Other parameters and data}

Other parameters and data are shown in Table 6. Inner Mongolia and Beijing have cooperated to establish a cross-regional carbon emission trading mechanism (BCDR, 2016). We assume that CERs are traded in the Beijing carbon market. In this study, 16 quarters of quarterly price data for the Beijing carbon market in 2014-2018 are selected as the basis for calculating the $u, d, P_{u}, P_{m}, P_{d}$ and volatility $\sigma$ based on mature accounting methods (Hull, 2015). In addition, the discount rate and risk-free interest rate are 0.1 and 0.05 (Zhang et al., 2014), respectively.

Table 6 Other parameters and data

\begin{tabular}{lll}
\hline Parameters & Value & Data sources \\
\hline Discount rate & 0.1 & (Zhang et al., 2014) \\
Risk-free interest rate & 0.05 & \\
Initial CERs price (CNY/ton) & 65.29 & \\
CERs price volatility & 0.1285 \\
$u$ & 1.2621 \\
$d$ & 0.7923 \\
$P_{u}$ & 0.2572 \\
$P_{m}$ & 0.6650 \\
$P_{d}$ & 0.0778 \\
\hline
\end{tabular}




\section{Results and discussion}

\subsection{NPV and TIV of CCS and CCS-EWR}

The CERs prices of each node in the trinomial tree model are displayed in Table A1 of the Appendix A. 2019 is the time for the direct coal liquefaction plants to start operation and the year in which the CCS-EWR investment decision is made for the first time. 2020 is the possible time for the CCS-EWR to start operation; thus, the CERs prices are displayed since 2020. These prices may decrease to near zero or increase to tens of thousands of Chinese Yuan per ton. It is clear that the current CERs price in China is not enough to trigger CCS-EWR investment with an NPV of -1850.05 MCNY (Table 7). Thus, CCS-EWR investments should be abandoned according to the decision rule based on the NPV method. Investors will, however, choose to execute the option to defer because the ROV of 1858.99 MCNY can be obtained by deferred investments. In addition, additional EWR results in a significant decrease in investment economy of CCS-EWR. The reduction in water resource fees can weaken the negative impact of EWR. However, due to the high capital costs as well as operating and maintenance costs, the negative impact of EWR on the investment economy of CCS-EWR cannot be completely eliminated, even in the absence of water resource fees. Here, the preliminary conclusion is that the option to defer should be executed for CCS-EWR retrofits. Moreover, this result further validates the advantages of real option method in CCS-EWR investment evaluation.

Table 7 NPV, TIV and investment decisions. (unit: MCNY)

\begin{tabular}{lllll}
\hline & NPV & TIV & ROV & Investment decision \\
\hline CCS & -1686.49 & 13.91 & 1700.40 & To defer \\
CCS+EWR & -1850.05 & 8.94 & 1858.99 & To defer \\
CCS+EWR (exemption from water resource fees) & -1732.41 & 9.62 & 1742.03 & To defer \\
\hline
\end{tabular}

\subsection{Critical CERs prices and critical annual increments of water resource fees}

Critical CERs prices for CCS and CCS-EWR investments and critical annual increments of water resource fees in eliminating the negative impact of EWR on the investment economy of CCS-EWR are shown in Table 8. The critical CERs price for CCS-EWR retrofits is $7.15 \mathrm{CNY} /$ ton higher than that (141.95 CNY/ton) for CCS retrofits. In the condition of exemption from water resource fees, the critical annual increment of water resource fees in eliminating the negative impact of EWR is $1.21 \mathrm{CNY} /$ ton, which is substantially higher than the current level of $0.75 \mathrm{CNY} / \mathrm{ton}$. Therefore, constrained by gradually tightening carbon emission reductions and the contradiction between supply and demand of water 
resources, China needs to take more practical measures to promote CCS-EWR retrofits for large $\mathrm{CO}_{2}$ emission sources in water-deficient areas.

Table 8 Critical CERs prices and critical annual increment of water resource fees. (unit: CNY/ton)

\begin{tabular}{ccc}
\hline Variable & Object & Value \\
\hline Critical CERs prices & CCS & 141.95 \\
& CCS-EWR & 149.10 \\
Critical CERs prices (exemption from water resource fees) & CCS-EWR & 143.83 \\
Critical annual increment of water resource fees & & \\
(exemption from water resource fees) & EWR & 1.21 \\
\hline
\end{tabular}

\subsection{Annual investment probabilities and investment response time}

With the expansion of the trinomial tree model, the probability distribution becomes more dispersed, as shown in Fig. A2 of the Appendix A. Based on the NPV and TIV of CCS-EWR, we have preliminarily determined that CCS-EWR investment should be deferred until at least 2025 to obtain the maximum investment value (Fig. 6). Thereafter, the annual investment probability of CCS-EWR will increase to $0.80 \%$ in 2036 due to the possible increase in CERs prices. Because of the short lifetime, the capital costs per unit of CERs, however, increase significantly, and the income is significantly reduced, which would make the annual investment probability decline after 2036. Moreover, the investment response time and annual investment probabilities are not affected by the exemption from water resource fees or not. Overall, the investment opportunities in CCS-EWR technology are small.

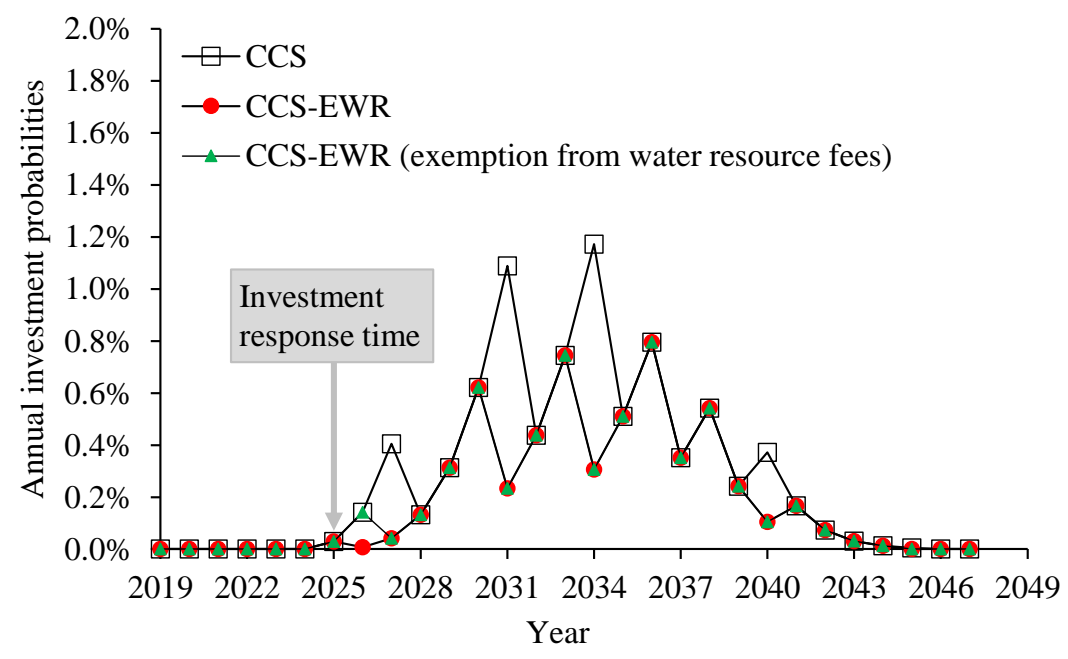

Fig. 6. Annual investment probabilities. 


\subsection{Scenario analysis}

EWR is an indispensable part of the CCS-EWR project. In addition, we have analysed the impact of the water resource fees on the economics of the CCS-EWR project investment. Next, when assessing the impact of uncertainties on the NPV, TIV, investment response time and annual investment probability, we only use CCS-EWR, which is exempt from water resource fees, as the assessment object.

\subsubsection{The influence of capital subsidies}

The capital subsidies given by the government can ameliorate the cash flow situation of CCS-EWR, especially for EWR. The high subsidy (80\%) realizes that the critical CERs price for CCS-EWR investments will be reduced by $25.84 \%$, and the critical CERs price for EWR investments will be reduced by $87.03 \%$, as shown in Fig. 7(b). In addition, a surprising finding is that the government incentives of exemption from water resource fees for freshwater recovered from saline water and a subsidy of $26 \%$ of the capital cost are sufficient in eliminating the negative impact of EWR on the investment economy of CCS-EWR. Moreover, although capital subsidies do not advance the response time of CCS-EWR investments greatly, they still have a significant impact on investment opportunities because the annual investment probabilities increase significantly in many years in the period of the option to defer (Fig. 7(c)). Capital subsidies should be the key measure to promote the demonstration of CCS-EWR in China.

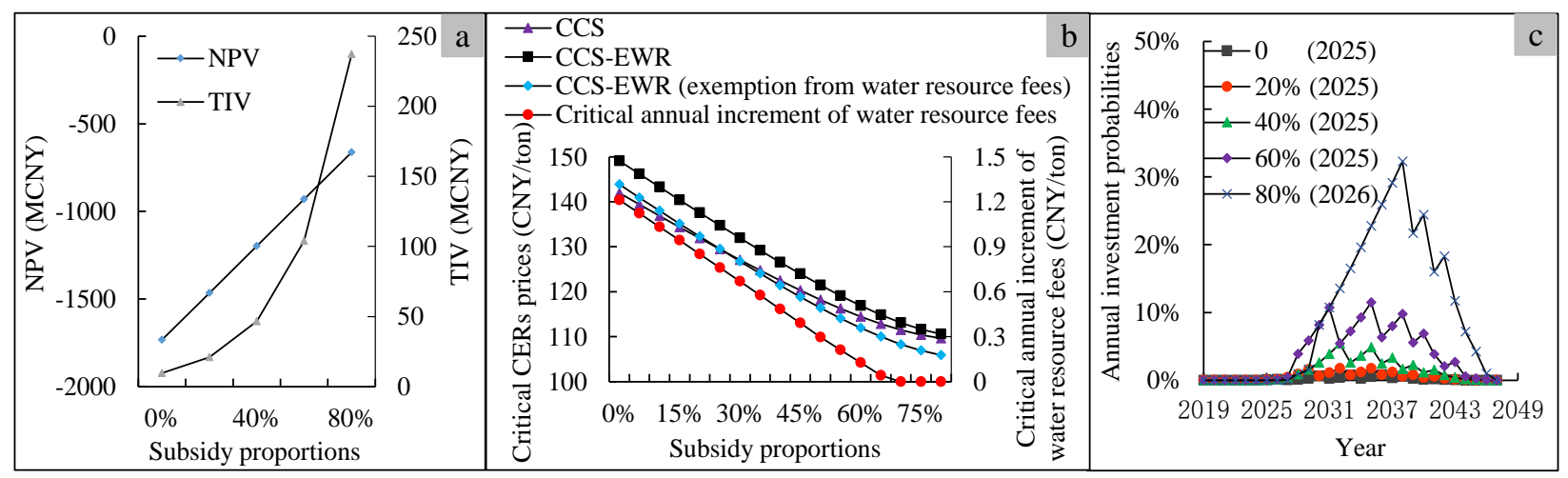

Fig. 7. The influence of capital subsidies on NPV (a), TIV (a), critical CERs prices (b), critical annual increment of water resource fees (b), annual investment probabilities (c) and investment response time (c).

The last column of the legend in Fig. 7(c) is the investment response time.

\subsubsection{The influence of water resource fees}

Since the initial water resource fees and annual increment of water resource fees selected in this study are very high in China (NDRC, 2012), the initial water resource fees and annual increment of water 
resource fees selected for scenario analysis are lower. From Fig. 8(a) and Fig. 8(c), the impact of water resource fees on NPV, TIV, investment response time and annual investment probability is weak. Under the circumstance of no exemption from water resource fees, the increase of $1 \mathrm{CNY} /$ ton in initial water resource fees and 0.15 CNY/ton in annual increment of water resource fees will increase the critical CERs price for CCS-EWR by approximately 2.34 CNY/ton, as shown in Fig. 8(b). Moreover, because the freshwater extracted from saline water cannot offset the consumption of freshwater by CCS-EWR, the increase in the initial water resource fees and annual increment of water resource fees reduces the investment feasibility of CCS-EWR under the circumstance of exemption from water resource fees. In addition, the increase of $1 \mathrm{CNY} /$ ton in initial water resource fees and $0.15 \mathrm{CNY} /$ ton in annual increment of water resource fees will decrease the critical annual increment of water resource fees by approximately $0.11 \mathrm{CNY} / \mathrm{ton}$. Due to the nature of EWR, exemption from water resource fees is not only applicable to promote CCS-EWR projects at present but also for future commercial CCS-EWR projects.

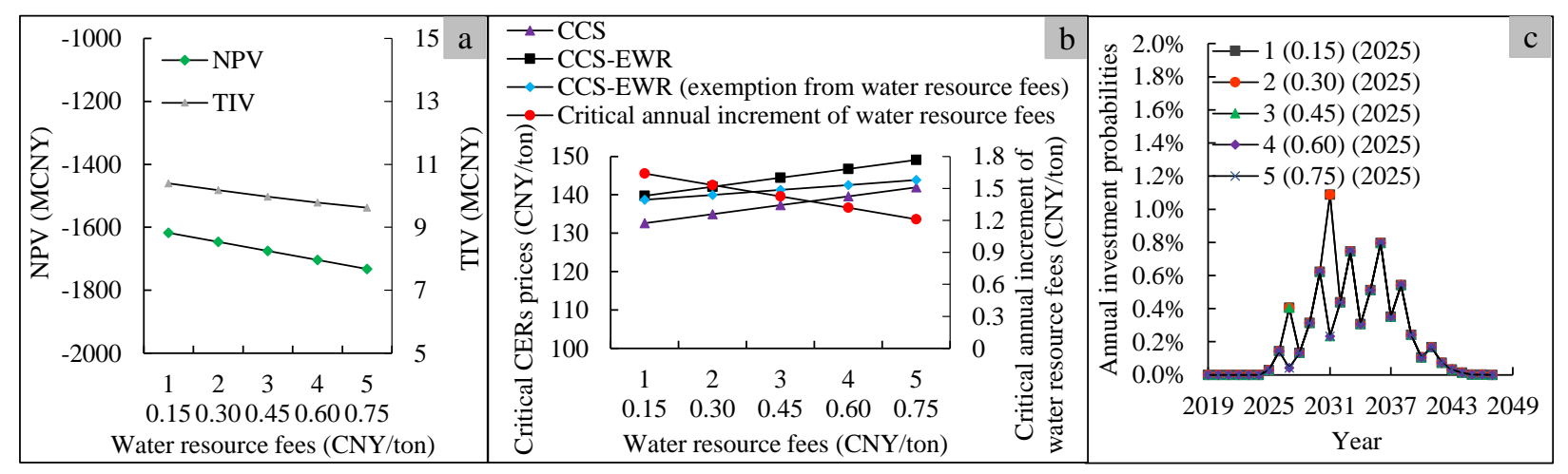

Fig. 8. The influence of water resource fees on NPV (a), TIV (a), critical CERs prices (b), critical annual increment of water resource fees (b), annual investment probabilities (c) and investment response time (c). The first line of the horizontal ordinate of Fig. 8(a) and Fig. 8(b), and the first column of the legend of Fig. 8 (c) is the initial water resource fees. The second line of the horizontal ordinate of Fig. 8(a) and Fig. 8(b), and the second column of the legend of Fig. 8(c) is the annual increment of water resource fees. The last column of the legend in Fig. 8(c) is the investment response time.

\subsubsection{The influence of the residual lifetime of direct coal liquefaction plants}

When the residual lifetime is less than 14 years, CCS-EWR projects are still unable to achieve profitability even with flexible management and decision making; therefore, direct coal liquefaction plants should abandon CCS-EWR investments, as shown in Fig. 9(a). Critical CERs prices and critical annual increments of water resource fees under various residual lifetimes $(\geqslant 14$ years) of direct coal liquefaction plants are displayed in Fig. 9(b). The ROV decreases gradually, while the capital costs per 
unit of CERs increase gradually as the residual lifetime decreases. Therefore, the critical CERs price for CCS-EWR investments decreases. In addition, water resource fees increase annually; thus, the longer the CCS-EWR service year is, the more significant the benefits of the exemption from water resource fees will be. Annual investment probabilities under various residual lifetimes are shown in Fig. 9(c). The annual investment probabilities would decline with shortened residual lifetimes.

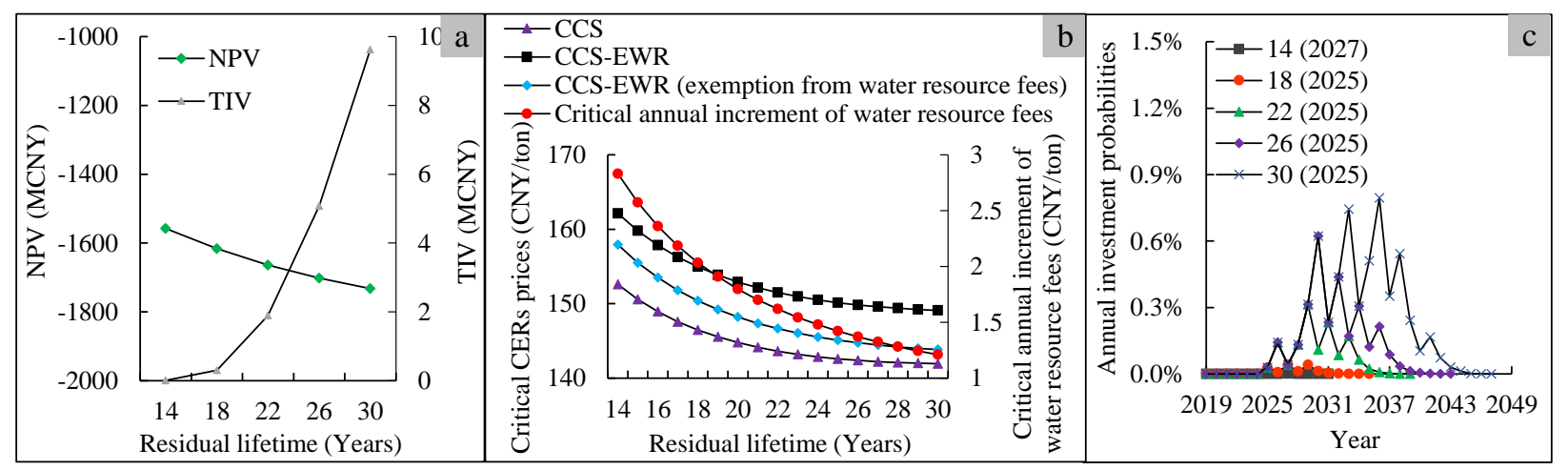

Fig. 9. The influence of residual lifetimes of direct coal liquefaction plants on NPV (a), TIV (a), critical CERs prices (b), critical annual increment of water resource fees (b), annual investment probabilities (c) and investment response time (c). The last column of the legend in Fig. 9(c) is the investment response time.

\subsubsection{The influence of $\mathrm{CO}_{2}$ and freshwater transport distance}

The costs of saline water transportation is higher than that of freshwater transportation. As the distance between the $\mathrm{CO}_{2}$ emission source and the storage site increases, investors will choose to increase the freshwater transportation distance instead of saline water transportation distance. With the increase in the length of $\mathrm{CO}_{2}$ and freshwater transport pipelines, the NPV and TIV decreases significantly as shown in Fig. 10(a), and investment opportunities are smaller as shown in Fig. 10(c). In addition, the investment response time is delayed by one year when the transportation distance of carbon dioxide increased to 80 $\mathrm{km}$. Moreover, the impact of the increase in $\mathrm{CO}_{2}$ and freshwater transport distance on the critical CERs prices and critical annual increment of water resource fees is also significant. Under the circumstance of exemption from water resource fees, the increase of $10 \mathrm{~km}$ in $\mathrm{CO}_{2}$ and freshwater transport distance will decrease the critical CERs prices for CCS-EWR by approximately $2.46 \mathrm{CNY} /$ ton and critical annual increment of water resource fees by approximately 0.07 CNY/ton, as shown in Fig. 10(b). 


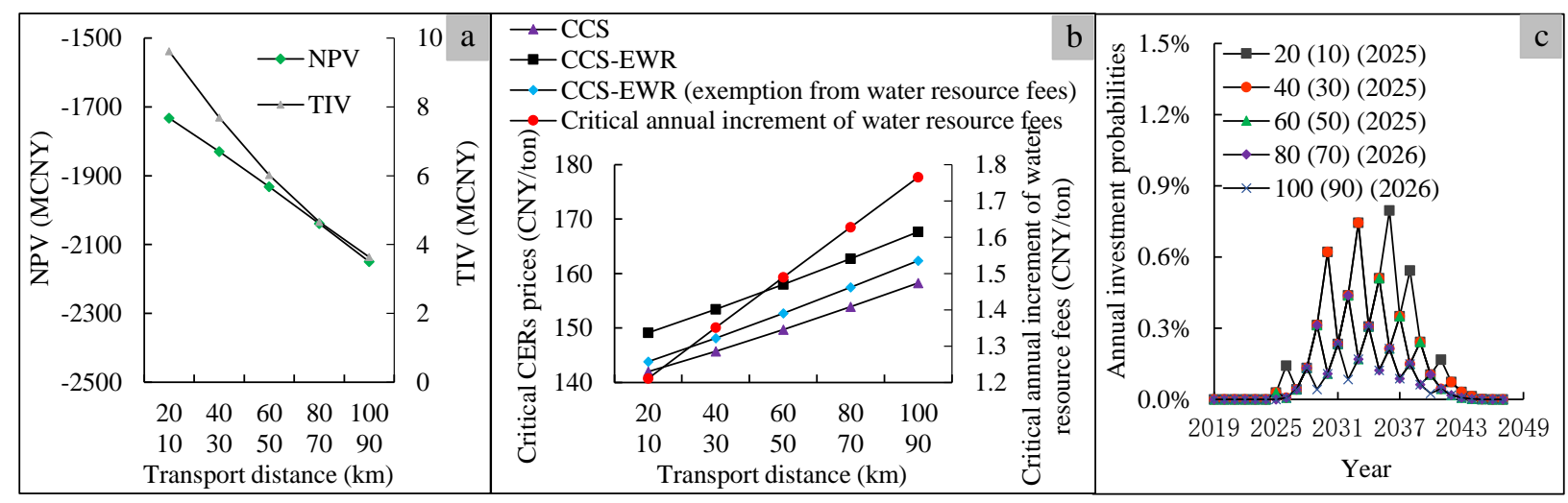

Fig. 10. The influence of $\mathrm{CO}_{2}$ and freshwater transport distance on NPV (a), TIV (a), critical CERs prices

(b), critical annual increment of water resource fees (b), annual investment probabilities (c) and investment response time (c). The first line of the horizontal ordinate of Fig. 10(a) and Fig. 10(b), and the first column of the legend of Fig. 10(c) is the $\mathrm{CO}_{2}$ transport distance. The second line of the horizontal ordinate of Fig. 10(a) and Fig. 10(b), and the second column of the legend of Fig. 10(c) is the freshwater transport distance. The last column of the legend in Fig. 10(c) is the investment response time.

\subsubsection{The influence of the amount of CERs}

Critical CERs prices under various amount of CERs are displayed in Fig. 11(b). With the decrease of the amount of CERs, critical CERs prices for CCS-EWR investments increase at accelerating levels. Under the circumstance of exemption from water resource fees, the critical CERs price for CCS-EWR increases by $66.18 \%$ when the ratio of the amount of CERs to that of $\mathrm{CO}_{2}$ captured decrease from $100 \%$ to $60 \%$. In addition, the amount of CERs are not directly related to the water resource fees; thus, there is no difference change in critical increment of water resource fees under different amount of CERs. Annual investment probabilities under the various amount of CERs are shown in Fig. 11(c). The reduction of the amount of CERs resulted in a significant decrease in the annual investment probability of CCS-EWR. In addition, when the ratio of the amount of CERs to that of $\mathrm{CO}_{2}$ captured is $60 \%$, the investment response time has been pushed back to 2028. Before CCS-EWR earnings are realized, treating the amount of captured $\mathrm{CO}_{2}$ as the amount of CERs is an alternative approach to stimulate CCS-EWR investment, although it is not meet the methodology for accounting CERs (IEAGHG, 2007; Philibert et al., 2007). 


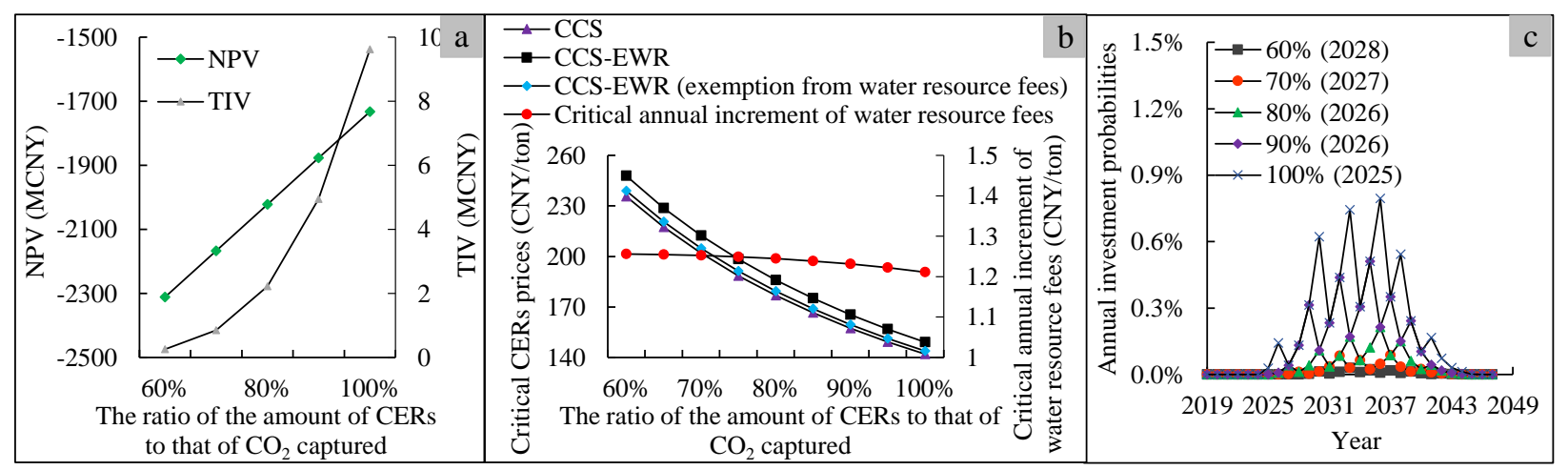

Fig. 11. The influence of ratio of the amount of CERs to that of $\mathrm{CO}_{2}$ captured on NPV (a), TIV (a), critical CERs prices (b), critical annual increment of water resource fees (b), annual investment probabilities (c) and investment response time (c). The last column of the legend in Fig. 11(c) is the investment response time.

\subsubsection{The influence of the volatility of CERs prices}

The greater the volatility is, the greater the ROV, as shown in Fig. 12(a). This is exactly in line with the principle of American call real option construction based on risk-neutral theory that the greater the uncertainty, the greater the ROV (Hull, 2015). Under the circumstance of exemption from water resource fees, the critical CERs price for CCS-EWR increases by $7.55 \mathrm{CNY} / \mathrm{t}$ when the volatility increases from 0.10 to 0.25 , as shown in Fig. 12(b). The response time shifts from 2023 to 2027 when the volatility decreases from 0.25 to 0.1 . Moreover, as the volatility increases, the overall investment opportunities also show an obvious increasing trend (Fig. 12(c)).

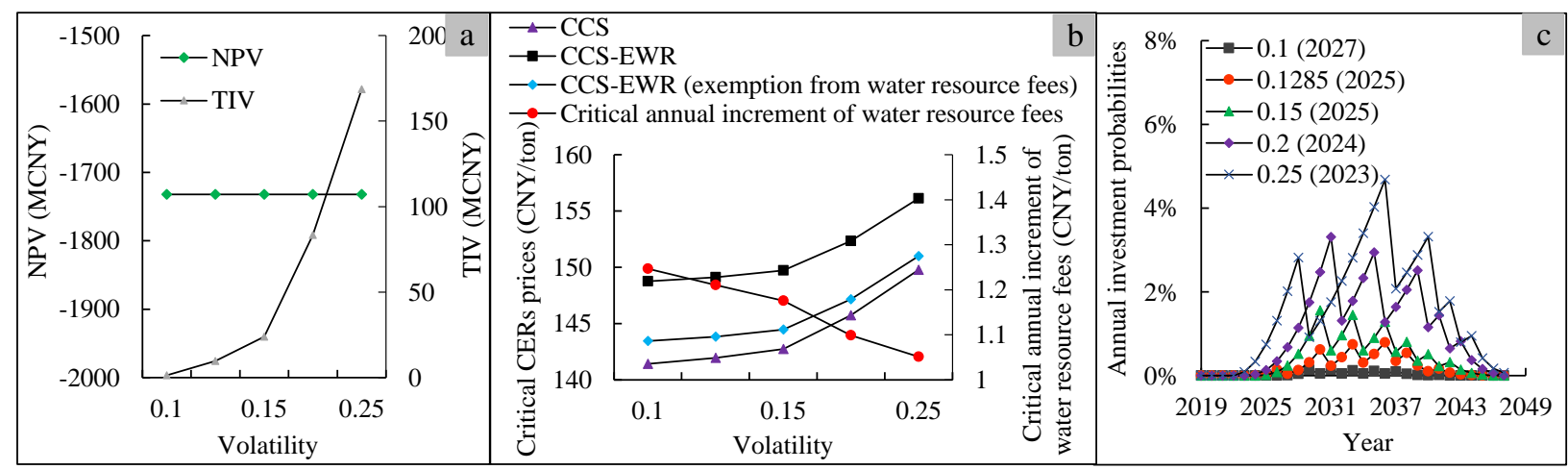

Fig. 12. The influence of the volatility of CERs prices on NPV (a), TIV (a), critical CERs prices (b), critical annual increment of water resource fees (b), annual investment probabilities (c) and investment response time (c). The last column of the legend in Fig. 12(c) is the investment response time. 


\subsubsection{The influence of electricity price}

Since the electricity price selected in Ordos are low in China (PowerKnowledge, 2018), the electricity price selected for scenario analysis are higher. From Fig. 13(c), the change in electricity price has no significant impact on investment opportunities. Under the circumstance of exemption from water resource fees, the increase of $0.05 \mathrm{CNY} / \mathrm{kWh}$ in initial electricity price and $0.001 \mathrm{CNY} / \mathrm{kWh}$ in annual increment of electricity price will increase the critical CERs price for CCS-EWR by approximately 5.79 $\mathrm{CNY} /$ ton. Electricity prices are not directly related to the water resource fees; thus, there is no significant difference in critical increment of water resource fees under different electricity prices, as shown in Fig. 13(b).

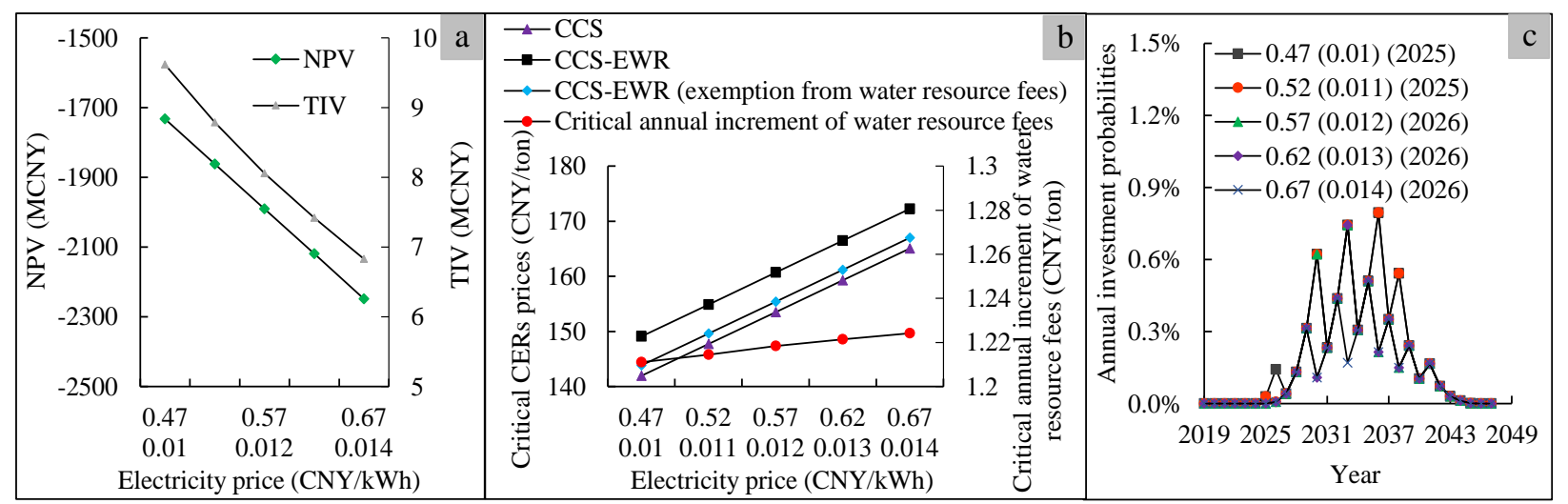

Fig. 13. The influence of electricity price on NPV (a), TIV (a), critical CERs prices (b), critical annual increment of water resource fees (b), annual investment probabilities (c) and investment response time (c). The first line of the horizontal ordinate of Fig. 13(a) and Fig. 13(b), and the first column of the legend of Fig. 13(c) is the initial electricity price. The second line of the horizontal ordinate of Fig. 13(a) and Fig. 13(b), and the second column of the legend of Fig. 13(c) is the annual increment of electricity price. The last column of the legend in Fig. 13(c) is the investment response time.

\section{Concluding Remarks}

CCS-EWR investment faces huge costs, multiple uncertainties and flexible investment timing, which correspond to the characteristics of a project should be evaluated using the real option approach. Thus, this article treats CCS-EWR investment as an option. A trinomial tree modelling-based real option approach was developed to evaluate the NPV, TIV, critical CERs price, investment response time and annual investment probability in CCS-EWR retrofitting for direct coal liquefaction plants, and the critical annual increments of water resource fees in eliminating the negative impact of EWR on the investment economy of CCS-EWR in China. Uncertainties in CERs prices, electricity prices, capital subsidies, water 
resource fees, the residual lifetime of direct coal liquefaction plants, $\mathrm{CO}_{2}$ and freshwater transport distance, and the amount of CERs were considered in this paper. The research framework and methodology in this article have universal applicability.

Considering such high capital costs, operating and maintenance costs, and the ROV, the current CERs price in China is not sufficient to trigger CCS-EWR investment unless it rises to $149.10 \mathrm{CNY} / \mathrm{ton}$. Investors will defer investments in pursuit of maximum profits. However, the investment feasibility is not optimistic. In addition, the critical CERs price for EWR investment is $7.15 \mathrm{CNY} /$ ton, which adversely affects the economics of the CCS-EWR system.

The influences of various factors were quantitatively investigated. The CERs price uncertainty is the key factor that causes investors to hold a wait-and-see attitude towards CCS-EWR investment. The higher the CERs price uncertainty is, the earlier the investment may be implemented. When the residual lifetime is less than 14 years, CCS-EWR projects are still unable to achieve profitability even with flexible management and decision making; therefore, direct coal liquefaction plants should abandon CCS-EWR investments. In analysing the impact of capital subsidies and exemption from water resource fees, it is inspiring to find that the government incentives of exemption from water resource fees for freshwater recovered from saline water and a subsidy of $26 \%$ of the capital cost are sufficient in eliminating the negative impact of EWR on the investment economy of CCS-EWR. The result of this case study, in principle, show the role and contribution of EWR technology with exemption from water resource fees for investment in CCS-EWR systems. Therefore, in addition to conventional capital subsidies, we suggest that exemption from water resource fees should be implemented for freshwater from CCS-EWR in consideration of CCS-EWR characteristics and current water resource policies. With reference to the suggested approach, investors in CCS-EWR projects could seek more support from governments. It should be noted here that fresh water recovered from saline water effectively reduces the consumption of water resources, but does not completely offset the fresh water consumed by CCS-EWR. Therefore, the development of CCS-EWR technology in water-deficient areas may be subject to shortage of water resources. However, compared to other CCS technologies, the CCS-EWR technology is subject to much lower constraints. It should be the most suitable type of CCS technology for development in areas with water shortages. In addition, the revenue of CCS-EWR is mainly derived from the transaction of CERs. The decrease of the amount of CERs has a significant impact on investment decisions. Before CCS-EWR earnings are realized, treating the amount of captured $\mathrm{CO}_{2}$ as the amount of CERs is an alternative approach to stimulate CCS-EWR investment, although it is not to properly meet the requirements for accounting the amount of CERs.

In addition, the boundary of CCS and EWR introduced in this paper could be utilized to promote the understanding of the technical aspects included in CCS-EWR technology. It is also a reference for future 
studies in economic evaluations and project management.

This study simply assumes a completely independent business model for CCS-EWR projects. Funding and project implementation are undertaken by one enterprise. However, technology development is often accompanied by changes in business models (Esposito et al., 2011), which is the same for CCS-EWR technology. An extension of this study is to explore the investment feasibility of CCS-EWR in new business models.

\section{Appendix A}

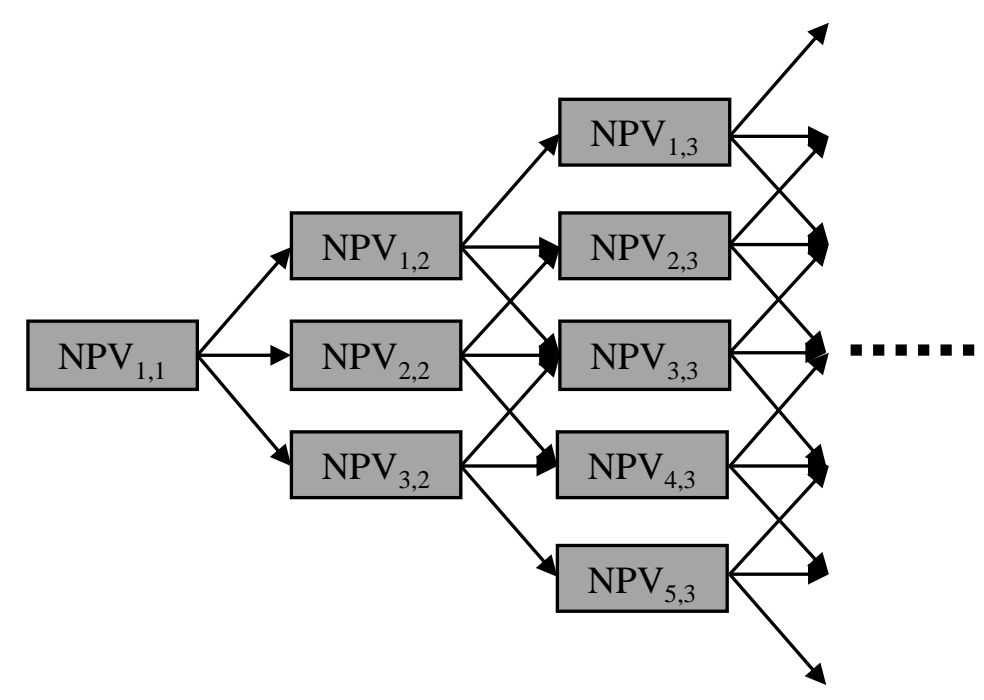

Fig. A1. NPV of each node of the trinomial tree model in the period of the option to defer.

Table A1 CERs prices of each node of the trinomial tree model (unit: CNY/ton)

\begin{tabular}{ccccc}
\hline 2020 & 2021 & 2022 & 2023 & $\ldots$ \\
\hline- & - & - & - & $\ldots$ \\
- & - & - & 131.27 & $\ldots$ \\
- & - & 104.01 & 104.01 & $\ldots$ \\
- & 82.41 & 82.41 & 82.41 & $\ldots$ \\
65.29 & 65.29 & 65.29 & 65.29 & $\ldots$ \\
- & 51.73 & 51.73 & 51.73 & $\ldots$ \\
- & - & 40.99 & 40.99 & $\ldots$ \\
- & - & - & 25.73 & $\ldots$ \\
- & - & - & - & $\ldots$ \\
\hline
\end{tabular}




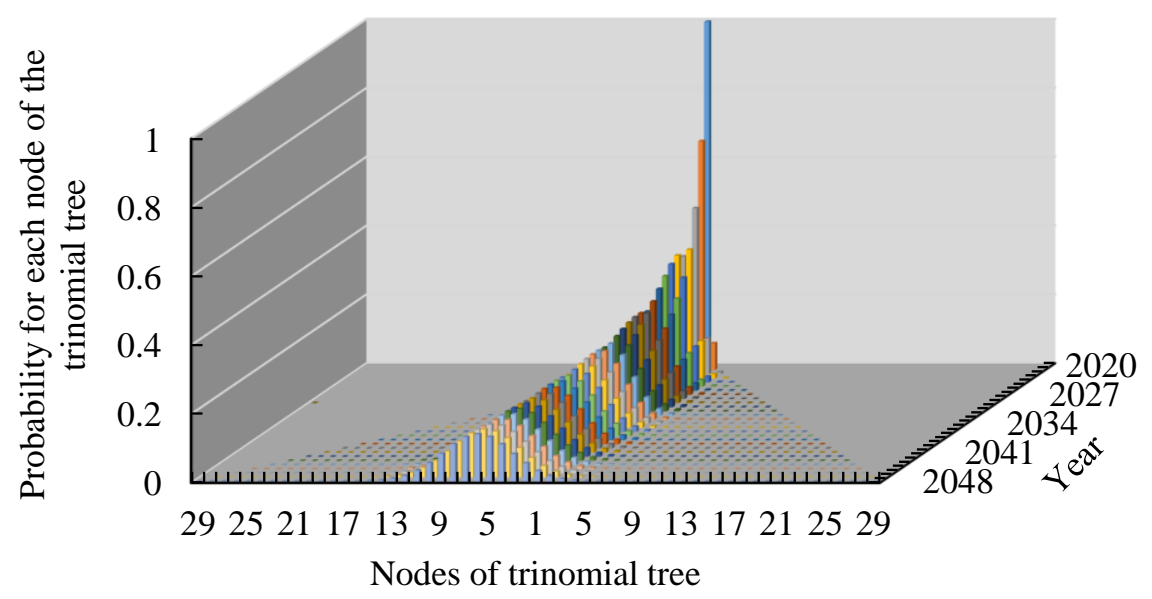

Fig. A2. Investment probabilities for each node of the trinomial tree.

\section{Acknowledgements}

This work was supported by China's National Key R\&D Program (2016YFA0602603) and the National Natural Science Foundation of China (Grant Nos. 71521002, 71601020 and 71642004). 


\section{References}

Abadie, L.M., Chamorro, J.M., 2008. European $\mathrm{CO}_{2}$ prices and carbon capture investments. Energy Econ. 30, 2992-3015.

Ahn, J., Song, M., 2007. Convergence of the trinomial tree method for pricing European/American options. Appl. Math. Comput 189, 575-582.

Balajewicz, M., Toivanen, J., 2017. Reduced order models for pricing European and American options under stochastic volatility and jump-diffusion models. J. Comput. Sci-Neth 20, 198-204.

BCDR (Beijing Municipal Commission of Development and Reform), 2016. Notice on relevant matters of cooperation in the cross-regional carbon emissions trading between Beijing and Inner Mongolia. (In Chinese). http://www.bjpc.gov.cn/zwxx/tztg/201603/t10058058.htm (accessed 26 October 2017).

Birkholzer, J.T., Zhou, Q., Tsang, C.F., 2009. Large-scale impact of $\mathrm{CO}_{2}$ storage in deep saline aquifers: A sensitivity study on pressure response in stratified systems. Int. J. Greenh. Gas Control 3, 181-194.

Bourcier, W.L., Wolery, T.J., Wolfe, T., Haussmann, C., Buscheck, T.A., Aines, R.D., 2011. A preliminary cost and engineering estimate for desalinating produced formation water associated with carbon dioxide capture and storage. Int. J. Greenh. Gas Control 5, 1319-1328.

Buscheck, T.A., Bielicki, J.M., White, J.A., Sun, Y., Hao, Y., Bourcier, W.L., Carroll, S.A., Aines, R.D., 2016. Pre-injection brine production in $\mathrm{CO}_{2}$ storage reservoirs: An approach to augment the development, operation, and performance of CCS while generating water. Int. J. Greenh. Gas Control 54, 499-512.

Buscheck, T.A., Sun, Y., Chen, M., Hao, Y., Wolery, T.J., Bourcier, W.L., Court, B., Celia, M.A., Friedmann, S.J., Aines, R.D., 2012. Active $\mathrm{CO}_{2}$ reservoir management for carbon storage: Analysis of operational strategies to relieve pressure buildup and improve injectivity. Int. J. Greenh. Gas Control 6, 230-245.

CCSIC (Carbon capture and storage information center), 2016. The role of carbon market in promoting carbon capture, utilisation and storage in http://www.captureready.com/EN/Channels/News/showDetail.asp?objID=4696\&isNew= (accessed 28 September 2017).

CEECPIP (Chemical Engineering Essentials for the CPI Professional), 2019. The chemical engineering plant cost index. https://www.chemengonline.com/pci-home (accessed 7 July 2019).

Chu, H., Ran, L., Zhang, R., 2016. Evaluating CCS investment of China by a novel real option-based model. Math. Probl. Eng. 2016, 1-15.

Dahowski, R.T., Davidson, C.L., Li, X.C., Wei, N., 2012. A \$70/t CO 2 greenhouse gas mitigation backstop for China's industrial and electric power sectors: Insights from a comprehensive CCS cost curve. Int. J. Greenh. Gas Control 11, 73-85.

EDOC, 2017. CEPCI June 2017 Issue. https://edoc.site/cepci-june-2017-issue-2-pdf-free.html (accessed 28 November 2018).

EHBWRMO (Ejin Horo Banner Water Resources Management Office), 2012. Collection scope and standard of water resources fees in Ejin Horo Banner water conservancy bureau. (In Chinese). http://www.yjhl.gov.cn/yqxzfw/qq_yjhlq/qq_yjhlq_0249/201210/t20121024_703011.html (accessed 25 July 2017).

Esposito, R.A., Monroe, L.S., Friedman, J.S., 2011. Deployment models for commercialized carbon capture and storage. Environ. Sci. Technol. 45, 139-146.

Fang, Q., Li, Y., 2014. Exhaustive brine production and complete $\mathrm{CO}_{2}$ storage in Jianghan basin of China. Environ. 
Earth Sci. 72, 1541-1553.

FERC (Federal Energy Regulatory Commission), 2018. Oil pipeline index. https://www.ferc.gov/industries/oil/gen-info/pipeline-index.asp (accessed 27 November 2018).

Fuss, S., Szolgayova, J., Obersteiner, M., Gusti, M., 2008. Investment under market and climate policy uncertainty. Appl. Energy 85, 708-721.

GOPGO (General Office of the People's Government of Ordos), 2017. An action plan for improving the comprehensive competitiveness of coal industry in Ordos (2016-2018). (In Chinese). http://xxgk.ordos.gov.cn/information/ordos xxw50/msg10204251134.html (accessed 27 January 2018).

Grillo, S., Blanco, G., Schaerer, C.E., 2015. Path integration for real options. Appl. Math. Comput 265, 120-132.

Hoeghguldberg, O., Bruno, J.F., 2010. The impact of climate change on the world's marine ecosystems. Sci 328, 1523-1528.

Huchzermeier, A., Loch, C.H., 2001. Project management under risk: using the real options approach to evaluate flexibility in R\&D. Manage. Sci. 47, 85-101.

Hull, J.C., 2015. Options, futures and other derivatives. Pearson Education Inc, London.

IEA (International Energy Agency), 2016. 20 years of carbon capture and storage - Accelerating future deployment. https://www.iea.org/publications/freepublications/publication/20-years-of-carbon-capture-and-storage.html (accessed 15 November 2018).

IEAGHG (International Energy Agency Greenhouse Gas Research and Development Programme), 2007. ERM Carbon dioxide capture and storage in the clean development mechanism. http://www.ccsassociation.org/docs/2007/2007\%20TR2CCS\%20CDM\%20methodology\%20.pdf $\quad$ (accessed 29 October 2018).

IMDRC (Inner Mongolia Development and Reform Commission), 2015. Notice for reducing the feed-in tariffs of coal-fired power and the electricity price of general industrial and commercial. (In Chinese). http://www.nmgfgw.gov.cn/fggz/jfjg/gzdt/201504/t20150419 107277.html (accessed 28 January 2018).

Insley, M.C., 2003. On the option to invest in pollution control under a regime of tradable emissions allowances. Can. J. Econ. 36, 860-883.

IPCC, 2005. IPCC special report on carbon dioxide capture and storage. Cambridge University Press, Cambridge, UK. IPCC, 2014. Climate change 2014: Mitigation of climate change. Cambridge University Press, Cambridge, UK.

IPCC, 2015. Climate change 2014: Synthesis report summary for policymakers. Cambridge University Press, Cambridge, UK.

Işlegen, Ö., Reichelstein, S., 2011. Carbon capture by fossil fuel power plants: An economic analysis. Manage. Sci. 57, 21-39.

Klapperich, R.J., Cowan, R.M., Gorecki, C.D., Liu, G., Bremer, J.M., Holubnyak, Y.I., Kalenze, N.S., Knudsen, D.J., Saini, D., Botnen, L.S., 2013. IEAGHG investigation of extraction of formation water from $\mathrm{CO}_{2}$ storage. Energy Procedia 37, 2479-2486.

Kobos, P.H., Cappelle, M.A., Krumhansl, J.L., Dewers, T.A., Mcnemar, A., Borns, D.J., 2011. Combining power plant water needs and carbon dioxide storage using saline formations: Implications for carbon dioxide and water management policies. Int. J. Greenh. Gas Control 5, 899-910.

Kulatilaka, N., Perotti, E.C., 1998. Strategic growth options. Manage. Sci. 44, 1021-1031.

Leeson, D., Dowell, N.M., Shah, N., Petit, C., Fennell, P.S., 2017. A Techno-economic analysis and systematic review of carbon capture and storage (CCS) applied to the iron and steel, cement, oil refining and pulp and paper 
industries, as well as other high purity sources. Int. J. Greenh. Gas Control 61, 71-84.

Li, Q., Fei, W., Liu, X., Wei, X., Jing, M., Li, X., 2015. Challenging combination of $\mathrm{CO}_{2}$ geological storage and coal mining in the Ordos basin, China. Greenhouse Gas Sci. Technol. 4, 452-467.

$\mathrm{Li}$, Q., Wei, Y., 2013. Progress in Combination of $\mathrm{CO}_{2}$ Geological Storage and Deep Saline Water Recovery. Sci. Technol. Rev., 65-70. (In Chinese).

Li, Q., Wei, Y.N., Liu, G., Lin, Q., 2014. Combination of $\mathrm{CO}_{2}$ geological storage with deep saline water recovery in western China: Insights from numerical analyses. Appl. Energy 116, 101-110.

Mantripragada, H.C., Rubin, E.S., 2011. Techno-economic evaluation of coal-to-liquids (CTL) plants with carbon capture and sequestration. Energy Policy 39, 2808-2816.

McCollum, D.L., Ogden, J.M., 2006. Techno-economic models for carbon dioxide compression, transport, and storage \& correlations for estimating carbon dioxide density and viscosity. Working paper, Institute of Transportation Studies, University of California.

Mi, Z., Meng, J., Guan, D., Shan, Y., Liu, Z., Wang, Y., Feng, K., Wei, Y.M., 2017a. Pattern changes in determinants of Chinese emissions. Environ. Res. Lett. 12, 1-10.

Mi, Z., Meng, J., Guan, D., Shan, Y., Song, M., Wei, Y.M., Liu, Z., Hubacek, K., 2017b. Chinese $\mathrm{CO}_{2}$ emission flows have reversed since the global financial crisis. Nat. commun. 8, 1-10.

Myers, S.C., 1984. Finance theory and financial strategy. Interfaces 14, 126-137.

NDRC (National Development and Reform Commission), 2012. Notice on issues concerning the standards for the collection of water resource fees. (In Chinese). http://www.ndrc.gov.cn/rdzt/2012xxgkgz/igsfxxgk/201301/t20130114 522936.html (accessed 14 October 2018).

NDRC (National Development and Reform Commission), 2014. Interim measures for the administration of carbon emission permit trading. http://qhs.ndrc.gov.cn/gzdt/201412/t20141212 652035.html (accessed 28 January 2018). NDRC (National Development and Reform Commission), 2016. China's policies and actions for addressing climate change (2016). (In Chinese). http://qhs.ndrc.gov.cn/zcfg/201611/W020161108342237594465.pdf (accessed 25 September 2017).

NEA (National Energy Administration), 2017. The 13th Five-Year Plan for coal deep processing industry demonstration. (In Chinese). http://zfxxgk.nea.gov.cn/auto83/201703/t20170303 2606.htm?keywords= (accessed 15 July 2017).

ODRC (Ordos Development and Reform Commission), 2017. Adjusted schemes of Ordos sewage treatment fee standard. (In Chinese). http://www.ordosfgw.gov.cn/hdjl/dczj/201703/t20170301 1899548.html (accessed 28 January 2018).

Ordos, 2018. Geographical environment. (In Chinese). http://www.ordos.gov.cn/zjordos/dlhj/ (accessed 28 January 2018).

PCEPA (Planning and Construction and Environmental Protection Agency), 2009. Ejin Horo Banner running-water company service standard. (In Chinese). http://www.yjhl.gov.cn/yqxxgk zyk/qq yihlq 10367/qq yihlq 0245/200912/t20091208 567863.html (accessed 28 September 2017).

PGIMAR (People's Government of Inner Mongolia Autonomous Region), 2014. Collection standards and related regulations of Inner Mongolia autonomous region water resources fees. (In Chinese). http://www.nmg.gov.cn/xxgkml/zzqzf/gkml/201509/t20150915 495077.html (accessed 4 July 2017).

Philibert, C., Ellis, J., Podkanski, J., 2007. Carbon capture and storage in the CDM. 
http://www.indiaenvironmentportal.org.in/content/252125/carbon-capture-and-storage-in-the-cdm/ (accessed 22 October 2017).

PowerKnowledge, 2018. Sales electricity price in various provinces of China. (In Chinese). http://www.jsdsm.gov.cn/dsmsite/2jdxw/2236.jhtml (accessed 14 October 2018).

Renner, M., 2014. Carbon prices and CCS investment: A comparative study between the European Union and China. Energy Policy 75, 327-340.

Rohlfs, W., Madlener, R., 2011. Valuation of CCS-ready coal-fired power plants: a multi-dimensional real options approach. Energy Syst. 2, 243-261.

Rosenzweig, C., Parry, M.L., 1994. Potential impact of climate change on world food supply. Nature 367, 133-138.

Scott, V., Gilfillan, S., Markusson, N., Chalmers, H., Haszeldine, R.S., 2013. Last chance for carbon capture and storage. Nat. Clim. Change 3, 105-111.

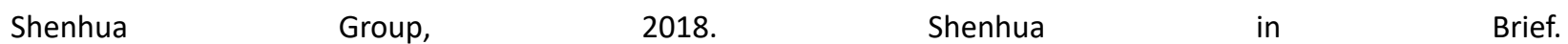
http://www.shenhuagroup.com.cn/shenhuaEn/1382682985012/Shenhua in Brief.shtml (accessed 28 January 2018).

Siddiqui, A.S., Marnay, C., Wiser, R.H., 2005. Real options valuation of US federal renewable energy research, development, demonstration, and deployment. Energy Policy 35, 265-279.

Song, M.I., Cui, L.B., 2016. Economic evaluation of Chinese electricity price marketization based on dynamic computational general equilibrium model. Comput. Ind. Eng. 101, 614-628.

Sullivan, E.J., Chu, S., Stauffer, P.H., Middleton, R.S., Pawar, R.J., 2013. A method and cost model for treatment of water extracted during geologic $\mathrm{CO}_{2}$ storage. Int. J. Greenh. Gas Control 12, 372-381.

Tang, B.J., Zhou, H.L., Chen, H., Wang, K., Cao, H., 2017. Investment opportunity in China's overseas oil project: An empirical analysis based on real option approach. Energy Policy 105, 17-26.

U.S. BLS (U.S. Bureau of Labor Statistics), 2018. Producer price index by industry: Drilling oil and gas wells: Drilling oil, gas, dry, or service wells (DISCONTINUED) [PCU21311121311101]. https://fred.stlouisfed.org/series/PCU21311121311101 (accessed 27 November 2018).

UNFCCC (United Nations Framework Convention on Climate Change), 2013. Proposed new carbon capture and storage baseline and monitoring methodology form (Version 02.0). http://cdm.unfccc.int/filestorage/e/x/t/extfile-20131007162532380-MethCCS form09.pdf/MethCCS form09.pdf?t =aDJ8cDhjOHNofDAU tPJP6TzKaAI6DWD93tu (accessed 6 March 2018).

Vatavuk, W.M., 2002. Updating the CE plant cost index: changing ways of building plants are reflected as this widely used index is brought into the 21st century. Chem. Eng., 62-70.

Venetsanos, K., Angelopoulou, P., Tsoutsos, T., 2002. Renewable energy sources project appraisal under uncertainty: the case of wind energy exploitation within a changing energy market environment. Energy Policy 30, 293-307.

Wei, Y.M., Mi, Z.F., Huang, Z., 2014. Climate policy modeling: An online SCI-E and SSCI based literature review. Omega 57, 70-84.

Wolery, T., Aines, R., Hao, Y., Bourcier, W., Wolfe, T., Haussman, C., 2009. Fresh water generation from aquifer-pressured carbon storage. https://e-reports-ext.Innl.gov/pdf/376002.pdf (accessed 15 September 2018).

$\mathrm{Wu}, \mathrm{X} ., 2013$. Carbon dioxide capture and grological storage: The first massive exploration in China, first ed. Science Press, Beiling. (In Chinese).

Xiang, D., Yang, S., Liu, X., Mai, Z., Qian, Y., 2014. Techno-economic performance of the coal-to-olefins process with CCS. Chem. Eng. J 240, 45-54. 
Yuen, F.L., Yang, H., 2010. Option pricing with regime switching by trinomial tree method. J. Comput. Appl. Math 233, 1821-1833.

Zhai, M., Lin, Q., Zhong, L., Pi, J., Wang, W., 2016. Economic assessment of carbon capture and storage combined with utilization of deep saline water. Mod. Cast. Iron 36, 8-12. (In Chinese).

Zhang, X., Wang, X., Chen, J., Xie, X., Wang, K., Wei, Y., 2014. A novel modeling based real option approach for CCS investment evaluation under multiple uncertainties. Appl. Energy 113, 1059-1067.

Zhou, W., Bing, Z., Chen, D., Zhao, F., Fei, W., 2011. Technoeconomic assessment of China's indirect coal liquefaction projects with different $\mathrm{CO}_{2}$ capture alternatives. Energy 36, 6559-6566.

Zhou, W., Bing, Z., Fuss, S., Szolgayová, J., Obersteiner, M., Fei, W., 2010. Uncertainty modeling of CCS investment strategy in China's power sector. Appl. Energy 87, 2392-2400.

Zhou, W., Zhu, B., Chen, D., Zhao, F., Fei, W., 2014. How policy choice affects investment in low-carbon technology: The case of $\mathrm{CO}_{2}$ capture in indirect coal liquefaction in China. Energy 73, 670-679.

Ziolkowska, J.R., 2015. Is desalination affordable?-regional cost and price analysis. Water Resour. Manage. 29, 1385-1397. 